\title{
1 Alpha-synuclein alters the faecal viromes of rats in a gut-initiated model of Parkinson's
}

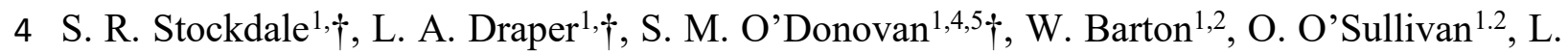

5 A. Volpicelli-Daley ${ }^{3}$, A. M. Sullivan ${ }^{1,4}$, C. O’Neill ${ }^{1,5, *}$, C. Hill ${ }^{1,6, *}$

$7 \quad$ APC Microbiome Ireland, University College Cork, Co. Cork, Ireland

$8{ }^{2}$ Teagasc Food Research Centre, Moorepark, Fermoy, Co. Cork, Ireland

$9{ }^{3}$ Civitan International Research Center, University of Alabama, Birmingham, USA

$10{ }^{4}$ Department of Anatomy and Neuroscience, University College Cork, Co. Cork, Ireland

$11{ }^{5}$ School of Biochemistry, University College Cork, Co. Cork, Ireland

$12{ }^{6}$ School of Microbiology, University College Cork, Co. Cork, Ireland

14 These authors contributed equally to this work.

$15{ }^{*}$ Corresponding authors: c.oneill@ucc.ie and c.hill@ucc.ie

17 Keywords: Parkinson's disease, faecal virome, alpha-synuclein, faecal phage, rat 18 microbiome, rat virome, rat phage 


\section{Abstract}

21 misfolding of alpha-synuclein ( $\alpha$-syn) into Lewy body aggregates within nerve cells that

22 contribute to their neurodegeneration. Recent evidence suggests $\alpha$-syn aggregation may begin

23 in the gut and travel to the brain along the vagus nerve, with microbes a potential trigger

24 initiating the misfolding of $\alpha$-syn. However, changes in the gut virome in response to $\alpha$-syn

25 alterations have not been investigated. In this study, we show longitudinal changes in the

26 faecal virome of rats administered either monomeric or preformed fibrils (PFF) of $\alpha$-syn

27 directly into their enteric nervous system. Differential changes in rat viromes were observed

28 when comparing monomeric and PFF $\alpha$-syn. The virome $\beta$-diversity changes after $\alpha$-syn

29 treatment were compounded by the addition of LPS as an adjunct. Changes in the diversity of

30 rat faecal viromes were observed after one month and did not resolve within the study's five

31 month observational period. Overall, these results suggest that microbiome alterations

32 associated with PD may, partially, be reactive to host $\alpha$-syn associated changes.

\section{Introduction}

Parkinson's disease (PD) is the second most common progressive neurodegenerative

36 disorder, affecting $0.1-0.2 \%$ of the population at any given time. This frequency increases

37 with age, with more than $1 \%$ of individuals over 60 living with PD ${ }^{1}$. While the overall cost

38 of PD varies from country to country, in the UK conservative and liberal estimates calculated

39 the annual cost of the illness between $£ 449$ million and $£ 3.3$ billion, respectively ${ }^{2}$. As the

40 mean age of populations increase, the social and economic burden of PD will rise. In fact,

41 worldwide cases of PD are expected to double to 14 million by $2040^{3}$; therefore, a greater

42 understanding of the disease and new interventions are urgently required. 
bioRxiv preprint doi: https://doi.org/10.1101/2021.03.29.437468; this version posted March 29, 2021. The copyright holder for this preprint (which was not certified by peer review) is the author/funder, who has granted bioRxiv a license to display the preprint in perpetuity. It is made available under aCC-BY-NC-ND 4.0 International license.

Genetic and epidemiological studies investigating PD have not demonstrated a

44 specific aetiology that triggers PD. Instead, many hypothesise that PD is a multifactorial

45 disease involving a complex combination of host genetics and environmental factors ${ }^{4}$. The

46 pathophysiological onset of PD is associated with the loss of dopamine-producing neurons in

47 the pars compacta sub-region of the substantia nigra structure of the midbrain ${ }^{5}$. However,

48 patients typically only display Parkinsonism, the motor features associated with PD, after 50-

$4980 \%$ of dopaminergic neurons are $\operatorname{lost}^{6}$. The presynaptic neuronal protein alpha-synuclein $(\alpha-$

50 syn) is linked to the loss of dopaminergic neurons, whereby the monomeric form of $\alpha$-syn

51 aggregates within nerve cells into toxic Lewy body (LB) formations that disrupt cellular

52 homeostasis ${ }^{7}$.

Gastrointestinal (GI) comorbidities are frequently associated with PD, with cohorts

54 from independent studies reporting that $70-78 \%$ of patients experience excessive saliva, 30-

$5597 \%$ of individuals have difficulty swallowing, and $20-89 \%$ report constipation ${ }^{8}$. The non-

56 motor symptoms associated with PD may also involve $\alpha$-syn, as its aggregation is detected

57 earlier and more frequently in the enteric (i.e. gastrointestinal) nervous system of PD patients

$58{ }^{9,10}$. Recent animal models have also demonstrated the spread of pathologic $\alpha$-syn along the

59 gut-brain axis through the vagus nerve ${ }^{11-13}$. This has led researchers to investigate the GI

60 tract and its community of microbes as a potential environmental trigger for the aggregation

61 of $\alpha$-syn that may contribute to the development of PD.

62

There are $10^{13}$ to $10^{14}$ bacteria, archaea, fungi, and viruses associated with the human

63 body, known collectively as the microbiota. Non-culture-based approaches to study their

64 genomic material (microbiome) have demonstrated the GI composition of PD patients differs

65 from controls ${ }^{14-21}$. In addition, transplantation of human faecal microbiotas from either PD

66 patients and non-PD controls to mice resulted in a motor function decline amongst the mice

67 humanized with a PD microbiota ${ }^{22}$. Specific bacterial taxa, and even bacterial-infecting

68 viruses (termed bacteriophages or phages), have been proposed as potential contributors to 
bioRxiv preprint doi: https://doi.org/10.1101/2021.03.29.437468; this version posted March $29,2021$. The copyright holder for this preprint (which was not certified by peer review) is the author/funder, who has granted bioRxiv a license to display the preprint in perpetuity. It is made available under aCC-BY-NC-ND 4.0 International license.

69 PD 17,23. However, caution is often required when interpreting microbial changes associated

70 with specific conditions, as alterations observed in the microbiome may be causal, or

71 reactive, to human host-associated changes ${ }^{24}$.

In this study, we investigated if the viral component of the rat microbiome (virome)

73 changes in response to $\alpha$-syn injected into rat enteric nervous systems. This study was

74 specifically performed in young rats to distinguish if $\alpha$-syn could be associated with virome

75 changes independent of microbial changes that would occur during PD development in older

76 rats. Both the monomeric and aggregated fibrillar forms of $\alpha$-syn were injected directly into

77 the myenteric plexus of surgically-prepared rat duodenal walls, with and without

78 intraperitoneal injection of bacterial lipopolysaccharide (LPS) as a potential inflammatory

79 adjunct. Virome diversity changes were observed between rats receiving specific $\alpha$-syn

80 treatments, and also longitudinally across individual rats. Specific viruses and VCs were

81 noted as differentially abundant across treatment groups, with microbiome changes reacting

82 to $\alpha$-syn and potentially PD-inducing conditions.

83

84 Results

85 Defining the rat faecal virome.

86 Viruses of the rat microbiome were identified using database-dependent and -

87 independent approaches, applied to both the viral-enriched and whole-genome sequencing

88 (WGS) data (see Methods). Viral sequences identified in the viral-enriched and WGS data

89 were merged into a single database and made non-redundant by removing duplicate

90 sequences and retaining the larger of any two homologous sequences ( $\geq 90 \%$ identity and $\geq$

$9190 \%$ coverage). The majority of sequences in the final rat viral database originated from the

92 viral-enriched fraction of the microbiome $(3,506 / 4,009$ sequences). The largest viral contig 
bioRxiv preprint doi: https://doi.org/101101/2021.03.29.437468; this version posted March 29, 2021. The copyright holder for this preprint (which was not certified by peer review) is the author/funder, who has granted bioRxiv a license to display the preprint in perpetuity. It is made available under aCC-BY-NC-ND 4.0 International license.

93 was $291,209 \mathrm{bp}$ in length, while the mean and median length of viral contigs is 4,123 and

$941,621 \mathrm{bp}$, respectively (Figure 1a). employ random DNA amplification, such as multiple displacement amplification (MDA),

97 known to bias the viral composition towards small circular genetic elements. Therefore, the

98 relative abundance of specific viral taxa such as small single-stranded DNA Microviridae 99 may be more accurate than previous faecal virome studies ${ }^{25}$. The average raw sequencing 100 reads per sample for rat faecal viromes was 2,926,309 (max. 3,616,794, $\min .2,221,657$ ). The 101 rat faecal viromes analysed in this study were dominated by bacterial-infecting phage.

102 However, the term virome (and not "phageome") is used throughout this study, as this study's 103 viral-detecting protocol does not preclude the identification of rat-infecting viruses, and they 104 may be present amongst the 'Unclassified' viruses. Of the tailed Caudovirales phages assigned a putative familial taxonomic rank, Siphoviridae phages were the most abundant, with Myoviridae and Podoviridae phages 107 detected at decreasing frequencies (Figure 1b). All viral sequences identified within this 108 study were clustered into pseudogenera termed viral clusters (VCs) using the vContact2 gene 109 sharing network-based algorithm. A total of $920 \mathrm{VCs}$ were generated, with the largest cluster 110 containing 20 sequences.

112 While the rat faecal virome might have relatively few circular genomes, it is more likely that 113 greater sequencing depth is required to complete and circularize more viral genome 114 sequences. The viral sequences identified in this study were queried for the presence of phage 115 integrases and/or recombinases. Only $8.4 \%$ of phages possessed genes encoding for lysogenic 116 conversion that would facilitate integration and replication as a prophage (Figure 1d). 
bioRxiv preprint doi: https://doi org/10.1101/2021.03.29.437468; this version posted March 29, 2021. The copyright holder for this preprint (which was not certified by peer review) is the author/funder, who has granted bioRxiv a license to display the preprint in perpetuity. It is made available under aCC-BY-NC-ND 4.0 International license.

119 virome sequencing reads generated (Figure 1e; min. 47.6\%, max. 70.2\%). Therefore, a

120 significant proportion of the rat faecal virome is not analysed and could be considered as

121 "viral dark matter" ${ }^{26}$. While significantly lower than within the whole shotgun sequencing,

122 there are instances where the bacterial housekeeping gene, cpn60, is detected within the

123 virome sequencing data (Figure 1f). Therefore, potential bacterial contamination may have

124 been inadvertently categorised as viral, and a greater understanding of the rat microbiome

125 will be required to distinguish the origin of sequences.

127 The rat microbiome changes over time.

The male Sprague-Dawley rats employed in this study were approx. two months of

129 age at the study's onset and seven months old at its conclusion. Therefore, the potential

130 impact of time in shaping the rat faecal microbiome was investigated. During the

131 MetaPhlAn2 analysis of the WGS data, an average of 99.7 and $0.3 \%$ of the microbiome

132 sequencing reads that could be assigned to microbial taxa were classified as bacterial and

133 viral, respectively. A longitudinal axis to the rat faecal virome was obtained by aligning the

134 WGS sequencing data onto the final rat viral database. An average of 44,431 WGS

135 sequencing reads aligned to viral sequences (min. 572; max. 256,910; median 33,298).

There was a statistically significant change in the faecal virome and total microbiome

137 composition of the rats over the study's duration, with time explaining $14.6 \%$ and $13.3 \%$ of

138 their variances, respectively (Figures $2 \mathrm{a} \& \mathrm{~b}$ ). The two-dimensional separation of faecal

139 samples by dissimilarity ( $\beta$-diversity) was not driven by intra-sample composition ( $\alpha$ -

140 diversity). No statistical difference in $\alpha$-diversities after Bonferroni correction are observed in

141 rat faecal viromes by treatment group, examining either virome or WGS data (Supplementary

142 Table 1). The PCoA axes 1 and 2 for the microbiome data explain more of the variation than

143 for the virome data (28.5 and $15.5 \%$ versus 21.1 and $9.4 \%$, respectively). 
$\alpha$-syn alters the rat faecal virome.

As it is established that the rat faecal virome changed over the course of the study,

147 any alterations occurring in $\alpha$-syn injected rats need to be examined in light of the control

148 treatments, Sham and LPS. The Sham and LPS controls experienced 22.6 and 19.5\%

149 variance, respectively, in their viromes over the study's duration (Figures $3 a$ \& b). Less than

150 a $1 \%$ difference in the variance of the rat faecal viral compositions are observed in the rats

151 that received the $\alpha$-syn monomer or $\alpha$-syn monomer with LPS (28.0 and $27.6 \%$ variances

152 explained, respectively; Figures $3 c \& d$ ). However, the effect of the $\alpha$-syn monomer on rat

153 viromes is far greater than differences attributable to either the Sham or LPS control

154 treatments. The PFF form of $\alpha$-syn appears to have had only a small effect on the rat virome

155 relative to the Sham and LPS controls; however, the PFF plus LPS treatments caused the

156 greatest virome alteration (variances explained $23.9 \%$ and $30.8 \%$, respectively; Figures $3 \mathrm{e} \&$

157 f).

159 Changes in individual rat viromes.

In order to investigate if changes in the rat faecal virome were directional, whereby a

161 sample is not merely more or less similar to its baseline through random fluctuations, each

162 individual rat's faecal virome was investigated relative to its baseline state. Using Bray-

163 Curtis index values that indicate the dissimilarity of two given virome samples, it was

164 observed that the greatest variation in the rat faecal virome occurs between Base and T1,

165 compared to T1 and T5 (Figure 4a). There was no statistical difference in the dissimilarity

166 values between the 'Base vs T1' and 'Base vs T5'. Additionally, the virome at five months

167 was more frequently dissimilar to the baseline compared to the one-month time point (Figure $1684 b)$. 
bioRxiv preprint doi: https://doi.org/10.1101/2021.03.29.437468; this version posted March 29, 2021. The copyright holder for this preprint (which was not certified by peer review) is the author/funder, who has granted bioRxiv a license to display the preprint in perpetuity. It is made available under aCC-BY-NC-ND 4.0 International license.

For the individual rat viromes segregated by treatment conditions (Figures $4 c-h$ ), the

170 least variation was observed between the average Sham, LPS, and $\alpha$-syn monomer treatment

171 baselines versus T1 time points (Figures 4c-e). Whereas within the first month, the $\alpha$-syn

172 monomer plus LPS, the PFF $\alpha$-syn, and the PFF $\alpha$-syn plus LPS treatments had the least

173 similarity when averaged across rats (Figures $4 \mathrm{f}-\mathrm{h}$ ). The viromes of rats receiving the $\alpha$-syn

174 monomer plus LPS are the most dissimilar to their baseline after the study's five months

175 (Figure 4f).

Additionally, we investigated if virome changes associated with specific $\alpha$-syn

177 treatments were the result of cage effects. Each rat was assigned a numerical value and a code

178 based on its cage. For example, code C21-R2 specifies cage number 21 and rat 2. Two cages,

179 with 2-3 rats per cage, were used for each treatment. Looking at each individual rat, no

180 specific trend across any of the treatment conditions was observed, such as all the rats within

181 a specific cage dramatically differing at T1 or T5 relative to their baseline (Figures 4c-h).

182 Also, the average Bray-Curtis dissimilarity values were similar for each specific treatment

183 across the two corresponding cages.

185 Viral changes caused by $\alpha$-syn treatments.

If the $\alpha$-syn treatments investigated in this study altered the rat microbiome and/or

187 virome, it is expected that the abundance of viruses would be significantly altered in one or

188 more time points ( $\mathrm{p}$-value $<1 \mathrm{E}-05)$. The Sham and LPS treatment arms of this study resulted

189 in the fewest differential viral and VC changes (Figure 5a \& b). There were only two viruses

190 increased at the one- and five-month time points of the Sham-administered rats, while no

191 viruses were consistently altered amongst LPS treated rats.

193 increased differential abundance at the five-month time point (Figure 5c). The $\alpha$-syn 
bioRxiv preprint doi: https://doi org/10.1101/2021.03 29.437468; this version posted March 29,2021 . The copyright holder for this preprint (which was not certified by peer review) is the author/funder, who has granted bioRxiv a license to display the preprint in perpetuity. It is made available under aCC-BY-NC-ND 4.0 International license.

194 monomer treatment did not induce a change in a virus or virus cluster across the time-points

195 investigated. The $\alpha$-syn monomer plus LPS, the PFF, and the PFF plus LPS treatment arms of

196 the study all induced significant abundance changes in viruses or VCs consistent across T1

197 and T5 time points. These treatments caused decreased differential abundance in six, two, and

198 five viruses and viral clusters, respectively (Figures 5d-f). While the $\alpha$-syn monomer plus

199 LPS and the PFF treatments both increased two viral groups across both time points (Figures

$2005 \mathrm{~d} \& \mathrm{e})$.

201

202 Common viral changes across PD inducing treatments.

In order to discern if a common pattern of changes occurs across different treatment

204 conditions, all viruses and viral clusters that were noted to have a differential abundance at

205 any time point were compared across the treatments tested. A total of 78 viruses and viral

206 clusters, predicted from the virome sequencing and the WGS sequencing data, were recorded

207 as differentially abundant at one or more time points relative to their baseline (Figure 6). Of

208 these, the majority ( 48 of $78,61.5 \%$ ) were only altered in one treatment condition. These are

209 most probably the result of random changes that have occurred in the rat microbiome over the

210 course of the study.

211 Nine viruses or VCs were altered across both the T1 and T5 time points analysed,

212 supporting the hypothesis that these are permanent microbiome changes. Only four viruses

213 are concordantly changed across the Sham and LPS controls, seven in the $\alpha$-syn monomer

214 and $\alpha$-syn monomer plus LPS treatments, and finally, nine in the $\alpha$-syn PFF and $\alpha$-syn PFF

215 plus LPS treated rats. There was one virus with an increased differential abundance at T5

216 across all treatment groups (contig Rat_15_NODE_1829_length_1188_cov_3.973522).

217 Whereas a second viral contig (C22-R1-T5_NODE_102_length_3426_cov_2.959953) has

218 an increased differential abundance detected in all but the $\alpha$-syn PFF treatment group. 
219 Therefore, these two contigs may be fragments of the same altered virus, with the latter

220 sequence putative annotated as a Siphoviridae phage.

222 Discussion

There are a limited number of viral metagenomic analyses conducted on wild rats as

224 they are a potential source of zoonotic infections ${ }^{27-29}$. However, despite their frequent use as

225 models of human diseases, to our knowledge, the virome of lab rats has not been investigated

226 (see Methods). In this study, the majority of faecal viruses analysed are putatively annotated

227 as tailed phages belonging to the Siphoviridae, Myoviridae, and Podoviridae families, with

228 few Microviridae observed. A similar trend is observed in the accumulative relative

229 abundance of viral taxa within microbiome sequencing data (Supplementary figure 1). These

230 top-level hierarchical viral taxa are similarly observed in the faeces of mice and humans ${ }^{30,31}$.

231 Unlike many mammalian faecal virome analyses, advances in sequencing

232 technologies have enabled us to conduct our analysis without a nucleic acid amplification

233 step. Therefore, the relative abundance of viral taxa and overall diversity of viromes

234 presented here is likely to be more accurate than previous studies. With a sequencing depth of

235 approximately $3 \mathrm{M}$ reads per sample, fewer genomes than expected were circular. Without the

236 random amplification bias towards small circular viral elements, and an overall better

237 representation of the virome diversity within the microbiome, an even greater sequencing

238 depth may be required to complete metagenomic viral genomes. On average, there were more

239 lytic than lysogenic phages noted in the rat virome, and this did not statistically differ over

240 the study's duration (Supplementary figure 2). However, the relative abundance of lytic

241 phages decreased ( $p$-value $<0.05$ ) in the monomeric $\alpha$-syn plus LPS and PFF treatment

242 groups, relative to the study's Sham treatment group. This was investigated because changes

243 in the ratio of lytic to lysogenic phages were observed in a comparison of healthy and 244 inflammatory bowel disease human viromes ${ }^{32}$. 
bioRxiv preprint doi: https://doi.org/10.1101/2021 03.29.437468; this version posted March 29, 2021. The copyright holder for this preprint (which was not certified by peer review) is the author/funder, who has granted bioRxiv a license to display the preprint in perpetuity. It is made available under aCC-BY-NC-ND 4.0 International license.

The majority of the rat faecal virome can be considered as 'dark matter', whereby

246 assembled sequences are unlike those deposited in reference databases. This is similar to

247 studies of the human virome, where $40-90 \%$ of sequences were unidentifiable ${ }^{33}$. In this

248 study, an average of $58.9 \%$ of the rat virome sequencing data could be aligned back to the

249 viral database generated from the sequencing of their faecal viromes. Therefore, while a

250 proportion of the virome sequencing data was not analysed, the remaining uncharacterised

251 data was a cautionary measure to prevent unintentional interpretation of bacterial-

252 contaminating sequences as viral.

The diversity of rat faecal viromes changed over the study's five-month duration. As

254 we are not aware of any published studies on the longitudinal rat faecal virome, it is difficult

255 to ascertain the cause(s) for this variation. Interestingly, the magnitude of change observed

256 for the whole microbiome and virome was similar using the same methodological procedures

257 (variances of $14.6 \%$ and $13.3 \%$, respectively). While this result may be coincidental, it would

258 be logical that changes in bacterial populations would have a concomitant effect on the

259 abundance of their viruses. One potential explanation for the shifts observed in the

260 microbiome and virome of rats over five months would be their accelerated aging relative to

261 humans. When comparing their lifespans, every 13.8 rat days approx. equates to a human

262 year ${ }^{34}$. Therefore, rats were potentially first analysed in this study during puberty and

263 reached social maturity at its conclusion. The virome changes associated with these

264 developmental periods are poorly described across all mammalian hosts.

266 inter-sample diversity must be interpreted cautiously. The variance $\left(\mathrm{R}^{2}\right)$ explained by viral $\beta$ -

267 diversities did not differ dramatically between the Sham, LPS, or $\alpha$-syn PFF treatments

$268(22.6 \%, 19.5 \%$, and $23.9 \%$, respectively). However, large $\beta$-diversity differences occurred

269 over the study's duration between control groups and rats administered the $\alpha$-syn monomer,

$270 \alpha$-syn monomer plus LPS, and $\alpha$-syn PFF plus LPS treatments $(28.0 \%, 27.6 \%$, and 30.8\%, 
bioRxiv preprint doi: https://doi org/10.1101/2021.03.29.437468; this version posted March 29 2021. The copyright holder for this preprint (which was not certified by peer review) is the author/funder, who has granted bioRxiv a license to display the preprint in perpetuity. It is made available under aCC-BY-NC-ND 4.0 International license.

271 respectively). Therefore, specific $\alpha$-syn treatments affected the overall longitudinal $\beta$ -

272 diversity of rats differently, with the fibril form of $\alpha$-syn with LPS injection as an

273 inflammatory adjunct resulting in the greater variance.

When broken down into an investigation of individual rat viromes, the greatest

275 variation was observed between the baseline and the first month, T1. However, the viromes

276 of rats continued to change between $\mathrm{T} 1$ and $\mathrm{T} 5$, and more frequently the viromes were more

277 dissimilar from their basal state at the five-month time point, T5. The magnitude by which

278 individual rat viromes transformed over the study was smallest for the Sham, LPS, and $\alpha$-syn

279 monomer treatments. Once more, the greatest changes observed in individual rats occurred in

280 those receiving the $\alpha$-syn monomer plus LPS, the $\alpha$-syn PFF, and $\alpha$-syn PFF plus LPS

281 treatments.

The individual viruses and VCs responsible for the rat faecal virome changes were investigated. A similar trend to the $\beta$-diversity analysis was observed across all of the study's

284 treatment groups. More viruses were differentially altered after five months, compared to one

285 month. Amongst the Sham rats investigated, only two viruses of VCs were differentially 286 altered at one month with the change maintained until the five-month time point. The LPS 287 treated control rats had no virus or VC altered across both time points. The abundance and 288 magnitude of viral changes are amplified in rats treated with the $\alpha$-syn monomer plus LPS, 289 the $\alpha$-syn PFF, and the $\alpha$-syn PFF plus LPS treated rats.

291 groups. Ideally, specific viruses would be altered across the various $\alpha$-syn treated rats 292 indicating a consistent effect on viral composition. However, few viruses and viral clusters 293 were differentially abundant across $\alpha$-syn treatments, examining either the monomeric or 294 fibrillar form of $\alpha$-syn with and without LPS (Supplementary figure 3). Taken together, viral 295 changes in the rat faecal virome may be indirectly associated with inflammatory or microbial 296 changes associated with $\alpha$-syn in the gut. However, no specific alteration in the virome could 
297 be definitively linked to the native or misfolded $\alpha$-syn, despite several viruses differentially

298 abundant across different treatments.

299 In conclusion, we present the first analysis of the lab rat faecal virome. The study

300 focused on the effect caused by the addition of $\alpha$-syn on the viral composition over five

301 months. There is clear evidence that the virome of rats changed following the injection of $\alpha-$

302 syn into the enteric nervous system. The magnitude of change observed across faecal viromes

303 was consistently greater amongst rats administer $\alpha$-syn monomer plus LPS, $\alpha$-syn PFF, or $\alpha$ -

304 syn PFF plus LPS. However, additional studies are required to clearly establish if $\alpha$-syn

305 induced virome alterations are associated with the pathogenesis or gastrointestinal

306 comorbidities of PD.

308 Methods

309 Generation of $\alpha-s y n$ PFFs.

Recombinant monomeric mouse $\alpha$-syn was purified and used to generate $\alpha$-syn PFFs,

311 as previously described ${ }^{35}$. A Pierce LAL high capacity endotoxin removal resin was used to

312 minimize endotoxin. Endotoxin levels were $0.017 \mathrm{Unit} / \mu \mathrm{g}$ of protein as determined using a

313 Pierce LAL endotoxin quantitation kit. Briefly, $\alpha$-syn monomer, kindly provided by Laura

314 Volpicelli-Daley, was thawed rapidly at $37^{\circ} \mathrm{C}$ in a $1.5 \mathrm{ml}$ microcentrifuge tube, then

315 centrifuged at $100,000 \mathrm{~g}$ at $4^{\circ} \mathrm{C}$ for $60 \mathrm{~min}$. The supernatant was removed and its protein

316 concentration was determined using a Nanodrop spectrophotometer, using the mouse $\alpha$-syn

317 coefficient $7450 \mathrm{M}^{-1} \mathrm{~cm}^{-1}$ and molecular weight approximately $15 \mathrm{kDa}$. The supernatant was

318 diluted in $50 \mathrm{mM}$ Tris $\mathrm{pH} 7.5,150 \mathrm{mM} \mathrm{KCL}$ to a final protein concentration of $5 \mathrm{mg} / \mathrm{ml}$. A

319 proportion of the solution was retained for subsequent ENS injection of $\alpha$-syn monomer. The

320 remainder was placed in a thermomixer at $37^{\circ} \mathrm{C}$ and shaken at 1000 r.p.m for 7 days.

321 Following 7 days, the clear solution became turbid, which is indicative of PFF formation. The 
bioRxiv preprint doi: https://doi org/10.1101/2021.03.29.437468; this version posted March 29, 2021. The copyright holder for this preprint (which was not certified by peer review) is the author/funder, who has granted bioRxiv a license to display the preprint in perpetuity. It is made available under aCC-BY-NC-ND 4.0 International license.

322 formation of PFFs was validated using the sedimentation assay and transmission electron

323 microscopy as previously described ${ }^{35}$. Immediately prior to surgery, PFFs were sonicated at

$32430 \%$ power on the Misonix Sonicator 3000, 1s on, $1 \mathrm{~s}$ off for $120 \mathrm{~s}$ total, in two 30 s sessions,

325 in order to break the fibrils into small fragments. Transmission electron micrographs showed

326 an aggregated protein structure, with filaments that are typical of PFFs. Measurement of fibril

327 length after sonication revealed that $>60 \%$ of the fibrils were less than $60 \mathrm{~nm}$ in diameter. A

328 sedimentation assay showed that there were approximately equal amounts of $\alpha$-syn PFFs in

329 the supernatant and pellet, indicating efficient PFF formation ${ }^{35}$.

331 Animal housing and husbandry.

Adult male Sprague-Dawley rats were purchased from Envigo, UK and maintained on

333 a $12 \mathrm{~h}: 12 \mathrm{~h}$ light:dark cycle (lights on at $08: 00 \mathrm{~h})$ at $21 \pm 2^{\circ} \mathrm{C}$ and humidity $(30-50 \%)$, with

334 access to standard rat chow and water ad libitum. All experiments were conducted in

335 accordance with the European Directive 2010/63/EU, and under a project authorization

336 issued by the Health Products Regulatory Authority, Ireland (AE19130/P036). Animals were

337 randomly divided into six treatment groups, as follows: (a) Sham: bovine serum albumin

338 (BSA) injected into duodenal wall $(n=12)$, (b) LPS: intraperitoneal (i.p.) injection of LPS

$339(\mathrm{n}=12),(\mathrm{c})$ monomer: $\alpha$-syn monomer injected into duodenal wall $(\mathrm{n}=12),(\mathrm{d})$ monomer plus

340 LPS: $\alpha$-syn monomer injected into duodenal wall plus an immediate i.p injection of LPS

341 ( $n=12)$, (e) PFF: PFF injected into duodenal wall ( $n=12)$, and (f) PFF plus LPS: PFF injected

342 into duodenal wall plus an immediate i.p injection of LPS $(n=12)$. Animals were housed three

343 per cage, according to their treatment group. After one month, six animals from each group

344 were culled and both gut and brain samples were retrieved for further analysis, the other six

345 were culled at five months. 


\section{Administration of $\alpha$-syn into the duodenal wall.}

Animals were anaesthetised using gaseous isoflurane (4-5\% to induce anaesthesia; 2 -

$3493 \%$ to maintain anaesthesia). On the day before surgery, animals were pre-treated

350 systemically with the non-steroidal anti-inflammatory analgesic, carprofen (Rimadyl®, $1 \mathrm{ml} /$

$351500 \mathrm{ml}$ drinking water). Animals were maintained at a constant body temperature by the use

352 of a heating pad. Each animal's abdomen was shaved and sterilised using betadine. The

353 laparotomy procedure was conducted as follows. A $2.5 \mathrm{~cm}$-incision was made vertically

354 along the abdomen using a sterile blade, then a scissors was used to cut through the muscle

355 layer. Approximately $3 \mathrm{~cm}$ in length of the stomach and the duodenum was partially exposed

356 to aid visualisation of the injection site. A Harvard automatic pump connected by tubing to a

$35750 \mu \mathrm{l}$ Hamilton syringe with a 25 -gauge needle was used to perform the injections. In order to

358 validate the injection procedure and the transmission from duodenal myenteric neurons to the

$359 \mathrm{CNS}, 2 \mu 1$ of $1 \%$ GFP-non-toxic fluorescent cholera toxin (Thermofisher, catalogue number

$360 \mathrm{C} 34775$ ) was injected as described previously ${ }^{36,37}$ into three sites in the duodenal wall.

361 Following this validation, $2 \mu 1$ of either mouse $\alpha$-syn monomer $(5 \mu \mathrm{g} / \mu \mathrm{l})$ or mouse PFF (5

$362 \mu \mathrm{g} / \mu \mathrm{l})$ was injected into each of these three sites. Animals in the LPS groups also received an

363 i.p. injection of LPS $(2.5 \mathrm{mg} / \mathrm{kg}$, in $0.9 \% \mathrm{w} / \mathrm{v}$ sterile saline $)$ immediately after the laparotomy

364 (LPS: Sigma, catalogue number L2630, 0111:B4) ${ }^{38}$. Sham animals received an injection of

365 BSA ( $2 \mu \mathrm{l}$ per site, $5 \mu \mathrm{g} / \mu \mathrm{l})$ into the duodenum, as previously described ${ }^{12,39-41}$ and LPS

366 animals only received $2.5 \mathrm{mg} / \mathrm{kg}$ LPS as i.p injection. All animals were treated for two days

367 following surgery with the non-steroidal anti-inflammatory analgesic, carprofen (Rimadyl ${ }^{2}$,

$3681 \mathrm{ml} / 500 \mathrm{ml}$ drinking water) to ensure pain relief.

370 Faecal collection and virome shotgun sequencing. 
bioRxiv preprint doi: https://doi.org/101101/2021.03.29.437468; this version posted March 29, 2021. The copyright holder for this preprint (which was not certified by peer review) is the author/funder, who has granted bioRxiv a license to display the preprint in perpetuity. It is made available under aCC-BY-NC-ND 4.0 International license.

Faecal pellets were directly extracted from animals at three time points; at the pre-

372 surgical baseline, termed: baseline, one month post-surgery (T1) and five months post-

373 surgery (T5). Samples were stored on dry ice and then frozen at $-80^{\circ} \mathrm{C}$. Nucleic

374 corresponding to the viromes of each group of rats was purified from faecal samples, with

375 approximately half a pellet per rat included in the extraction. Faecal samples were

376 homogenised in $10 \mathrm{ml} \mathrm{SM}$ buffer followed by centrifugation twice at $5,000 \mathrm{~g}$ at $10^{\circ} \mathrm{C}$ for 10

377 mins and filtration through a $0.45 \mu \mathrm{m}$ syringe filter to remove particulates and bacterial cells.

$378 \mathrm{NaCl}$ (0.5 M final concentration; Sigma) and 10\% w/v polyethylene glycol (PEG-8000;

379 Sigma) were added to the resulting filtrate and incubated at $4^{\circ} \mathrm{C}$ overnight. Following

380 centrifugation at $5,000 \mathrm{~g}$ at $4^{\circ} \mathrm{C}$ for 20 mins, the pellet was resuspended in $400 \mu 1 \mathrm{SM}$ buffer.

381 An equal volume of chloroform (Fisher) was added and following $30 \mathrm{sec}$ of vortexing the

382 sample was centrifuged at $2,500 \mathrm{~g}$ for $5 \mathrm{mins}$ at RT. The aqueous top layer was retained and

383 subjected to RNase I (10 U final concentration; Ambion) and DNase (20 U final

384 concentration; TURBO DNA-free ${ }^{\mathrm{TM}} \mathrm{Kit}$, Invitrogen) treatment in accordance with the

385 manufacturer's guidelines.

To isolate the nucleic acids, virus like particles were incubated with $20 \mu \mathrm{L}$ of $10 \%$

387 SDS and $2 \mu \mathrm{L}$ of proteinase $\mathrm{K}$ (Sigma, $20 \mathrm{mg} / \mathrm{mL}$ ) for $20 \mathrm{~min}$ at $56^{\circ} \mathrm{C}$, prior to lysis by the 388 addition of $100 \mu \mathrm{L}$ of Phage Lysis Buffer (4.5 M guanidine thiocyanate; $45 \mathrm{mM}$ sodium 389 citrate; $250 \mathrm{mM}$ sodium lauroyl sarcosinate; $562.5 \mathrm{mM} \beta$-mercaptoethanol; $\mathrm{pH} 7.0$ ) with 390 incubation at $65^{\circ} \mathrm{C}$ for $10 \mathrm{~min}$. Viral nucleic acid was purified by two treatments with an 391 equal volume of phenol:chloroform:isoamyl alcohol (25:24:1), finally passing it through a 392 QIAGEN Blood and Tissue Purification Kit and eluting samples in $30 \mu \mathrm{L}$ of AE Buffer. In 393 order to include any RNA viruses in the downstream analysis, $22 \mu 1$ of the eluent underwent 394 reverse transcriptase (RT) treatment (Superscript IV, Thermo Fisher) as per the 395 manufacturer's instructions, albeit doubling all volumes to increase the volume of template 396 used. Prior to library preparation this RT product was sonicated following adjustment of the 
bioRxiv preprint doi: https://doi.org/10.1101/2021 03.29.437468; this version posted March 29,2021 . The copyright holder for this preprint (which was not certified by peer review) is the author/funder, who has granted bioRxiv a license to display the preprint in perpetuity. It is made available under aCC-BY-NC-ND 4.0 International license.

397 volume to $52.5 \mu 1$ with low-EDTA TE buffer. Shearing of unamplified DNA/cDNA mixture

398 was performed on M220 Focused-Ultrasonicator (Covaris) with the following settings: peak

399 power of $50 \mathrm{~W}$, duty factor of $20 \%, 200$ cycles per burst, total duration of $35 \mathrm{sec}$. All steps

400 were performed in accordance with the manufacturer's protocol.

In order to concentrate the DNA/cDNA fragments entering the library, it was passed

402 through the Zymo Genomic DNA Clean \& Concentrator ${ }^{\mathrm{TM}}$ Kit, eluting in $17 \mu 1$ DNA Elution

403 Buffer supplied in the kit. Library preparation was carried out using Accel-NGS 1S Plus kit

404 (Swift Biosciences) according to manufacturer's instructions, with the addition of a final

405 purification step using a 1:1 DNA/AMPure beads ratio to eliminate any small fragment

406 contamination prior to sequencing. A single-indexed pooled library was sequenced using

$4072 \times 150$ nt paired-end sequencing run on an Illumina Novaseq platform at Genewiz, Germany.

409 Virome data processing.

411 was assessed pre- and post-processing using FastQC version $0.11 .3{ }^{42}$. Adaptors and

412 sequenced nucleotides demonstrating low quality were pruned using Trimmomatic version

4130.36 in paired-end mode, when the quality dropped below a Phred score of 30 for a $4 \mathrm{bp}$

414 sliding window ${ }^{43}$. While processed reads less than $70 \mathrm{bp}$ were dumped, the surviving paired

415 and unpaired reads were used in all subsequent analyses. The level of bacterial contamination

416 within the virome sequencing data was estimated by aligning reads against a cpn60 database

$417^{44}$.

Reads were assembled into contigs using metaSPAdes version 3.11.1. All contigs less

419 than $1,000 \mathrm{bp}$ were discarded. Within the virome sequencing, viruses were predicted through

420 several different procedures. The assembled sequences were queried against the NCBI viral

421 RefSeq database version 95 (E-value 1E-05) using BLAST version 2.6.0+ ${ }^{45}$. All circular 
bioRxiv preprint doi: https://doi org/10.1101/2021.03 29.437468; this version posted March 29, 2021. The copyright holder for this preprint (which was not certified by peer review) is the author/funder, who has granted bioRxiv a license to display the preprint in perpetuity. It is made available under aCC-BY-NC-ND 4.0 International license.

422 contigs detected in the virome sequencing were considered as viral. Assembled nucleotide

423 sequences were run through the VirSorter pipeline, where category 1 and 2 viruses were

424 examined further. Viral dark matter was detected by a BLASTn search against NCBI's NT

425 database, with assembled sequences from the viral-enriched shotgun data with no

426 representative in the NT database included in downstream analyses. Viral proteins were

427 predicted using Prodigal version 2.6.3 ${ }^{46}$ with the 'meta' option enabled and Shine-Dalgarno

428 training bypassed. Contig-encoded proteins were queried against the Prokaryotic Viral

429 Orthologous Groups database (pVOGs) using HMMER version 3.1.b2 ${ }^{47}$. The following cut-

430 offs were employed to detect sequences rich in viral proteins: contigs $<5 \mathrm{~kb}$ needed $\geq 3$

431 pVOG hits; $\geq 5$ and $<10 \mathrm{~kb}, 4$ pVOGs; $\geq 10$ and $<20 \mathrm{~kb}, 5$ pVOGs; $\geq 20$ and $<40 \mathrm{~kb}, 6$

432 pVOGs; $\geq 40$ and $<60 \mathrm{~kb}, 7$ pVOGs; and $\geq 60 \mathrm{~kb}, 8$ pVOGs. Sequences identified through the

433 different approaches were pooled together and made non-redundant, keeping the larger of

434 two sequences when the BLAST identity and coverage between sequences exceeded $90 \%$.

Subsequent to the detection of putative viruses in the rat faecal virome sequencing

436 data, potential contaminant sequences were removed as follows. The encoded proteins of all

437 putative viruses were queried against a database of ribosomal proteins. All contigs encoding

438 ribosomal proteins were removed from further analysis. Additionally, proteins were queried

439 for similarity to the Pfam plasmid replication proteins: PF01051, PF01446, PF01719,

440 PF04796, PF05732, and PF06970. Contigs containing a HMMER hit with a score $\geq 15$ were

441 discarded.

442 Virome sequencing reads were aligned to the final viral contigs database using the 443 WGS sequencing data (kindly supplied by Teagasc, Moorepark). While the virome 444 sequencing data was generated on pooled rat faecal samples, the WGS sequencing was 445 performed on multiple time points. Reads were aligned using Bowtie2 version 2.3.4.1 in end446 to-end mode ${ }^{48}$. The breadth of coverage of reads mapping across each viral contig was 447 calculated using the BEDTools version 2.26.0 coverage function ${ }^{49}$. In order to determine if a 
448 viral sequence was truly present, and not the result of multiple reads stacking onto a single

449 conserved element, the following breadth of coverage cut-offs were applied: minimum 3

450 sequencing reads; for contigs $<5 \mathrm{~kb}, 50 \%$ of the sequence needed to be covered in aligned

451 reads; contigs $\geq 5$ and $<20 \mathrm{~kb}, 30 \%$ of the sequence needed to be covered, and for contigs $\geq$

$45220 \mathrm{~kb}, 10 \%$ of the sequence needs to be covered. If the breadth of coverage filter was not met

453 for a specific contig within a sample, zero reads were recorded.

455 taxonomic rank, using vContact2 version $0.9 .8{ }^{50}$. VCs were generated using default settings

456 with the inclusion of known viruses from the Bacterial and Archaeal Viral RefSeq version 85,

457 with ICTV and NCBI taxonomy. The sequencing reads of viruses belonging to specific VCs

458 were aggregated. Viruses grouped into ambiguous vContact2 clusters (i.e. outliers, overlap)

459 were treated as singletons. Viruses not grouping into VCs were nonetheless retained during

460 the analysis. The putative familial-level taxonomic composition of viral sequences were

461 predicted using the Demovir script (https://github.com/feargalr/Demovir) with default

462 settings. Integrases and recombinases were identified amongst viral-encoded proteins using a

463 probabilistic hidden Markov model (HMM) generated from Pfam protein families; PF00239,

464 PF00589, PF02899, PF07508, PF09003, PF09299, PF10136, PF13356, PFF14659, PF16795,

465 and PF18644.

\section{Virome analysis.}

469 were drawn using 'ggplot2' 52, utilising the 'RColorBrewer' and 'jcolors' packages for colour

470 schemes ${ }^{53,54}$. Statistical comparisons were performed using the 'ggpubr' package ${ }^{55}$, with two

471 and multiple group comparisons executed through Wilcoxon and Kruskal-Wallis tests, 472 respectively. $\alpha$ - and $\beta$-diversities of samples were calculated with the 'vegan' and 'phyloseq' 
473 packages, respectively 56,57 . Differences in sample $\beta$-diversities displayed in this study were

474 calculated using the Bray-Curtis dissimilarity index with Principal Coordinate Analysis

475 (PCoA) two-dimensional ordination. Permutational multivariate analysis of variance

476 (PERMANOVA) statistical comparisons of PCoA-grouped samples was conducted with the

477 adonis function from the vegan package. Differential abundance changes in viruses and VCs

478 were calculated using the 'DESeq2' package ${ }^{58}$. Reported p-values were adjusted using

479 Bonferroni correction. The heatmap annotation bar was generated using the

480 'ComplexHeatmap' package ${ }^{59}$. Literature searches were conducted in PubMed, February

481 2020, using the search term: "rat" AND "phage" OR "rat" AND "phage".

482

\section{Frequent abbreviations}

484 PD, Parkinson's disease

$485 \alpha$-syn, Alpha-synuclein

486 LB, Lewy body

487 GI, Gastrointestinal

488 LPS; Lipopolysaccharide

489 WGS, Whole genome shotgun

490 VCs, Viral clusters

491 PFF, Pre-formed ( $\alpha$-syn) fibrils 
bioRxiv preprint doi: https://doi org/10.1101/2021.0329.437468; this version posted March 29,2021 . The copyright holder for this preprint (which was not certified by peer review) is the author/funder, who has granted bioRxiv a license to display the preprint in perpetuity. It is made available under aCC-BY-NC-ND 4.0 International license.

494 This publication has emanated from research conducted with the financial support of Science

495 Foundation Ireland under Grant numbers grant numbers SFI/12/RC/2273_P2 and SFI/14/SP

496 APC/B3032.

497

498 Author contributions

499 SMOD, AS and CON conceived the study. SMOD performed the animal study. AS and CON

500 supervised the animal study. LAD extracted and sequenced the faecal viromes. SRS

501 performed the analysis. WB and OOS conducted the WGS sequencing. LVD purified

502 monomeric $\alpha$-syn. SRS, LAD, SMOD, CON, and $\mathrm{CH}$ interpreted the results and wrote the

503 manuscript. $\mathrm{CON}$ and $\mathrm{CH}$ secured the funding.

504

505 Competing interests

506 The authors declare no conflict of interest.

507

508 Corresponding authors

509 Correspondence should be addressed to: c.hill@ucc.ie or c.oneill@ucc.ie

511 Data availability

512 The supplementary data and scripts required to generate the images and interpret the results

513 of this study are openly available in Figshare at http://doi.org/10.6084/m9.figshare.14332985.

\section{References}


516 1. Tysnes, O.-B. \& Storstein, A. Epidemiology of Parkinson's disease. J Neural Transm 124, 901-905

517 (2017).

518 2. Findley, L. J. The economic impact of Parkinson's disease. Parkinsonism \& Related Disorders 13,

519 S8-S12 (2007).

520 3. Johnson, M. E., Stecher, B., Labrie, V., Brundin, L. \& Brundin, P. Triggers, Facilitators, and

521 Aggravators: Redefining Parkinson's Disease Pathogenesis. Trends in Neurosciences 42, 4-13

522 (2019).

523 4. Warner, T. T. \& Schapira, A. H. V. Genetic and environmental factors in the cause of Parkinson's

524 disease. Ann Neurol. 53, S16-S25 (2003).

525 5. Surmeier, D. J. Determinants of dopaminergic neuron loss in Parkinson's disease. FEBS J 285,

$526 \quad 3657-3668$ (2018).

527 6. George DeMaagd \& Ashok Philip. Parkinson's Disease and Its Management. P T 40, 504-510

528 (2015).

529 7. Zhang, G. et al. New Perspectives on Roles of Alpha-Synuclein in Parkinson's Disease. Front. Aging

$530 \quad$ Neurosci. 10, 370 (2018).

531 8. Pfeiffer, R. F. Gastrointestinal dysfunction in Parkinson's disease. Parkinsonism \& Related

532 Disorders 17, 10-15 (2011).

533 9. Yan, F. et al. Gastrointestinal nervous system $\alpha$-synuclein as a potential biomarker of Parkinson 534 disease: Medicine 97, e11337 (2018).

535 10. Minguez-Castellanos, A. et al. Do -synuclein aggregates in autonomic plexuses predate Lewy 536 body disorders?: A cohort study. Neurology 68, 2012-2018 (2007).

537 11. Kim, S. et al. Transneuronal Propagation of Pathologic $\alpha$-Synuclein from the Gut to the Brain 538 Models Parkinson's Disease. Neuron 103, 627-641.e7 (2019).

539 12. Holmqvist, S. et al. Direct evidence of Parkinson pathology spread from the gastrointestinal 540 tract to the brain in rats. Acta Neuropathol 128, 805-820 (2014). 
541 13. Uemura, N. et al. Inoculation of $\alpha$-synuclein preformed fibrils into the mouse gastrointestinal

542 tract induces Lewy body-like aggregates in the brainstem via the vagus nerve. Mol

$543 \quad$ Neurodegeneration 13, 21 (2018).

544 14. Scheperjans, F. et al. Gut microbiota are related to Parkinson's disease and clinical phenotype.

545 Mov Disord. 30, 350-358 (2015).

546 15. Keshavarzian, A. et al. Colonic bacterial composition in Parkinson's disease: COLONIC

547 MICROBIOTA IN PARKINSON'S DISEASE. Mov Disord. 30, 1351-1360 (2015).

548 16. Bedarf, J. R. et al. Functional implications of microbial and viral gut metagenome changes in 549 early stage L-DOPA-naïve Parkinson's disease patients. Genome Med 9, 39 (2017).

550 17. Hill-Burns, E. M. et al. Parkinson's disease and Parkinson's disease medications have distinct

551 signatures of the gut microbiome: PD, Medications, and Gut Microbiome. Mov Disord. 32, 739749 (2017).

553 18. Heintz-Buschart, A. et al. The nasal and gut microbiome in Parkinson's disease and idiopathic

554 rapid eye movement sleep behavior disorder: Nose and Gut Microbiome in PD and iRBD. Mov

555 Disord. 33, 88-98 (2018).

556 19. Lin, A. et al. Gut microbiota in patients with Parkinson's disease in southern China.

557 Parkinsonism \& Related Disorders 53, 82-88 (2018).

558 20. Unger, M. M. et al. Short chain fatty acids and gut microbiota differ between patients with

559 Parkinson's disease and age-matched controls. Parkinsonism \& Related Disorders 32, 66-72

560 (2016).

561 21. Li, W. et al. Structural changes of gut microbiota in Parkinson's disease and its correlation with 562 clinical features. Sci. China Life Sci. 60, 1223-1233 (2017).

563 22. Sampson, T. R. et al. Gut Microbiota Regulate Motor Deficits and Neuroinflammation in a 564 Model of Parkinson's Disease. Cell 167, 1469-1480.e12 (2016).

565 23. Tetz, G., Brown, S. M., Hao, Y. \& Tetz, V. Parkinson's disease and bacteriophages as its 566 overlooked contributors. Sci Rep 8, 10812 (2018). 
567 24. Hanage, W. P. Microbiology: Microbiome science needs a healthy dose of scepticism. Nature 512, 247-248 (2014).

569 25. Ann C. Gregory, Olivier Zablocki, Allison Howell, Benjamin Bolduc \& Matthew B. Sullivan. The 570 human gut virome database. bioRxiv (2019) doi:10.1101/655910.

57126. Roux, S., Hallam, S. J., Woyke, T. \& Sullivan, M. B. Viral dark matter and virus-host interactions 572 resolved from publicly available microbial genomes. elife 4, e08490 (2015).

573 27. Tan, Z. et al. Virome profiling of rodents in Xinjiang Uygur Autonomous Region, China: Isolation 574 and characterization of a new strain of Wenzhou virus. Virology 529, 122-134 (2019).

575 28. Hansen, T. A. et al. High diversity of picornaviruses in rats from different continents revealed 576 by deep sequencing. Emerging Microbes \& Infections 5, 1-8 (2016).

577 29. Phan, T. G. et al. The Fecal Viral Flora of Wild Rodents. PLoS Pathog 7, e1002218 (2011).

578 30. Kim, M.-S. \& Bae, J.-W. Spatial disturbances in altered mucosal and luminal gut viromes of diet579 induced obese mice: Mucosal and luminal gut viromes. Environ Microbiol 18, 1498-1510 (2016).

580 31. Shkoporov, A. N. et al. The Human Gut Virome Is Highly Diverse, Stable, and Individual Specific. 581 Cell Host \& Microbe 26, 527-541.e5 (2019).

582 32. Clooney, A. G. et al. Whole-Virome Analysis Sheds Light on Viral Dark Matter in Inflammatory 583 Bowel Disease. Cell Host \& Microbe 26, 764-778.e5 (2019).

584 33. Krishnamurthy, S. R. \& Wang, D. Origins and challenges of viral dark matter. Virus Research 239, 136-142 (2017).

586 34. Pallav Sengupta. The Laboratory Rat: Relating Its Age With Human's. Int J Prev Med 4, 624-630 587 (2013).

588 35. Volpicelli-Daley, L. A. et al. Formation of $\alpha$-synuclein Lewy neurite-like aggregates in axons 589 impedes the transport of distinct endosomes. MBoC 25, 4010-4023 (2014).

$59036 . \quad$ Conte, W. L., Kamishina, H. \& Reep, R. L. Multiple neuroanatomical tract-tracing using 591 fluorescent Alexa Fluor conjugates of cholera toxin subunit B in rats. Nat Protoc 4, 1157-1166 592 (2009). 

made available under aCC-BY-NC-ND 4.0 International license.

593 37. Hyland, N. P., Abrahams, T. P., Fuchs, K., Burmeister, M. A. \& Hornby, P. J. Organization and

594 neurochemistry of vagal preganglionic neurons innervating the lower esophageal sphincter in

595 ferrets. J. Comp. Neurol. 430, 222-234 (2001).

596 38. Kelly, L. P. et al. Progression of intestinal permeability changes and alpha-synuclein expression

597 in a mouse model of Parkinson's disease: GI Dysfunction in a Premotor Model of PD. Mov Disord.

29, 999-1009 (2014).

599 39. Couch, Y., Alvarez-Erviti, L., Sibson, N. R., Wood, M. J. \& Anthony, D. C. The acute inflammatory response to intranigral $\alpha$-synuclein differs significantly from intranigral lipopolysaccharide and is exacerbated by peripheral inflammation. J Neuroinflammation 8, 166 (2011).

602 40. Freundt, E. C. et al. Neuron-to-neuron transmission of $\alpha$-synuclein fibrils through axonal transport. Ann Neurol. 72, 517-524 (2012).

604 41. George, S., Rey, N. L., Reichenbach, N., Steiner, J. A. \& Brundin, P. $\alpha$-Synuclein: The Long 605 Distance Runner: $\alpha$-Synuclein: The Long Distance Runner. Brain Pathology 23, 350-357 (2013).

606 42. Andrews, S. FastQC: a quality control tool for high throughput sequence data. (2010).

607 43. Bolger, A. M., Lohse, M. \& Usadel, B. Trimmomatic: a flexible trimmer for Illumina sequence 608 data. Bioinformatics 30, 2114-2120 (2014).

609 44. Hill, J. E. cpnDB: A Chaperonin Sequence Database. Genome Research 14, 1669-1675 (2004).

610 45. McGinnis, S. \& Madden, T. L. BLAST: at the core of a powerful and diverse set of sequence 611 analysis tools. Nucleic Acids Research 32, W20-W25 (2004).

612 46. Hyatt, D. et al. Prodigal: prokaryotic gene recognition and translation initiation site 613 identification. BMC Bioinformatics 11, 119 (2010).

614 47. Grazziotin, A. L., Koonin, E. V. \& Kristensen, D. M. Prokaryotic Virus Orthologous Groups 615 (pVOGs): a resource for comparative genomics and protein family annotation. Nucleic Acids Res 45, D491-D498 (2017).

617 48. Langmead, B. \& Salzberg, S. L. Fast gapped-read alignment with Bowtie 2. Nat Methods 9, 357618359 (2012). 
619 49. Quinlan, A. R. \& Hall, I. M. BEDTools: a flexible suite of utilities for comparing genomic

620 features. Bioinformatics 26, 841-842 (2010).

621 50. Bin Jang, H. et al. Taxonomic assignment of uncultivated prokaryotic virus genomes is enabled

622 by gene-sharing networks. Nat Biotechnol 37, 632-639 (2019).

623 51. R Core Team. R: A Language and Environment for Statistical Computing. https://www.R-

624 project.org/ (2019).

625 52. Wickham, H. ggplot2: Elegant Graphics for Data Analysis. (Springer-Verlag New York, 2016).

626 53. Erich Neuwirth. RColorBrewer: ColorBrewer Palettes. (2014).

627 54. Jared Huling. jcolors: Colors Palettes for R and 'ggplot2', Additional Themes for 'ggplot2'.

628 (2019).

629 55. Alboukadel Kassambara. ggpubr: 'ggplot2' Based Publication Ready Plots. (2019).

63056.5 Oksanen, J., Kindt, R., Legendre, P. \& O'Hara, B. VEGAN: R package for community ecology.

631 (2006).

632 57. McMurdie, P. J. \& Holmes, S. phyloseq: An R Package for Reproducible Interactive Analysis and 633 Graphics of Microbiome Census Data. PLoS ONE 8, e61217 (2013).

634 58. Love, M. I., Huber, W. \& Anders, S. Moderated estimation of fold change and dispersion for 635 RNA-seq data with DESeq2. Genome Biol 15, 550 (2014).

636 59. Zuguang Gu, Roland Eils \& Matthias Schlesner. Complex heatmaps reveal patterns and 637 correlations in multidimensional genomic data. (2016). 


\section{Figure legends}

639 Figure 1. The rat faecal virome. (a) Contig length (bp) versus sequencing coverage of 640 identifiable viruses present in the faeces of male rats. The shape aesthetic was used to 641 highlight the topology of assembled viral contigs, while colour represents proposed 642 taxonomic assignment. (b) The breakdown of rat faecal viruses into their putative familial643 level taxonomic assignments. (c) The topology of identified viral contigs, whereby circular 644 sequences are most likely complete genomes. (d) Viral contigs encoding a phage integrase 645 and/or recombinase were annotated as lysogenic phages. (e) The relative abundance of viral 646 contigs within the virome sequencing data, aggregated by taxonomic assignment. Sequencing 647 reads aligning to contigs not recognised as viral are omitted. (f) The relative abundance of the 648 bacterial house-keeping gene cpn60 detected in the virome sequencing data versus the WGS 649 data.

651 Figure 2. $\boldsymbol{\alpha}$ - and $\boldsymbol{\beta}$-diversity analysis of the rat faecal microbiome. Study time points T1 652 and T5 represent one and five months, respectively, and are grouped by ellipses. Two 653 dimensional PCoA ordination of rat faecal samples, using the Bray-Curtis dissimilarity index, 654 demonstrates the $\beta$-diversity between samples. The size of the sample points analysed 655 represents their $\alpha$-diversity Shannon index values. (a) WGS sequencing reads mapped onto 656 the identified rat faecal virome, and (b) relative abundance of bacterial species in the WGS 657 data.

659 Figure 3. $\alpha$ - and $\beta$-diversity analysis of the rat faecal virome by treatment condition.

660 Ellipses group samples by the study time points investigated. The size of sample points 661 represents their Shannon index $\alpha$-diversity, while the two dimensional PCoA ordination of 662 sample points represents their $\beta$-diversity dissimilarity using the Bray-Curtis index. The 
663 treatment conditions investigated in this study are; (a) Sham, (b) LPS, (c) $\alpha$-syn monomer,

664 (d) $\alpha$-syn monomer and LPS, (e) $\alpha$-syn PFF, and (f) $\alpha$-syn PFF and LPS.

666 Figure 4. Changes in the faecal virome of individual rats, separated by the treatment

667 conditions. (a) The Bray-Curtis dissimilarity index values for all rat faecal viromes between

668 study time points, with Wilcoxon test p-values shown. Points represent the specific Bray-

669 Curtis index values. (b) Summary of whether faecal viromes analysed were more dissimilar

670 from the study's baseline (Base) using the Bray-Curtis index after 1 month (T1) or 5 months

671 (T5). The left-hand image of treatment panels (c-h) demonstrates the Bray-Curtis

672 dissimilarity for individual rat faecal viromes. A horizontal solid grey line connects the 'Base

673 vs T1' and 'Base vs T5' Bray-Curtis values, while a horizontal dashed grey line indicates the

674 Bray-Curtis change between T1 and T5. Vertical dashed lines and numerical insets are colour

675 coded to indicate the average Bray-Curtis index values at the respective time points. The

676 right-hand image of each treatment panel specifies if T1 or T5 Bray-Curtis values are more

677 dissimilar from the Base.

679 Figure 5. Volcano plots showing differential abundance of rat faecal viruses and viral 680 clusters at one month (T1) and five months (T5) relative to the study's baseline. The 681 vertical dashed lines of each panel indicate $\log 2$ fold changes equivalent to +2 or -2 , while 682 the horizontal dashed line denotes a Bonferroni adjusted p-value significance of $1 \mathrm{E}-05$. The 683 axis values of all panels are scaled equivalently.

685 Figure 6. Viruses and viral clusters which were differentially abundant at statistical 686 significance in at least one of the study's time points, relative to the baseline. Viruses or 687 viral clusters that were differentially abundant across two or more treatment groups are 

made available under aCC-BY-NC-ND 4.0 International license.

688 connected using black dashed lines. The shape of each point indicates if the virus or viral

689 cluster had an increased or decreased differential abundance. The putative familial taxonomic

690 assignment of the various viruses is indicated to the right-hand side of the image. 
bioRxiv preprint doi: https://doi.org/10.1101/2021.03.29.437468; this version posted March 29, 2021. The copyright holder for this preprint (which was not certified by peer review) is the author/funder, who has granted bioRxiv a license to display the preprint in perpetuity. It is made available under aCC-BY-NC-ND 4.0 International license.

\section{Figures:}
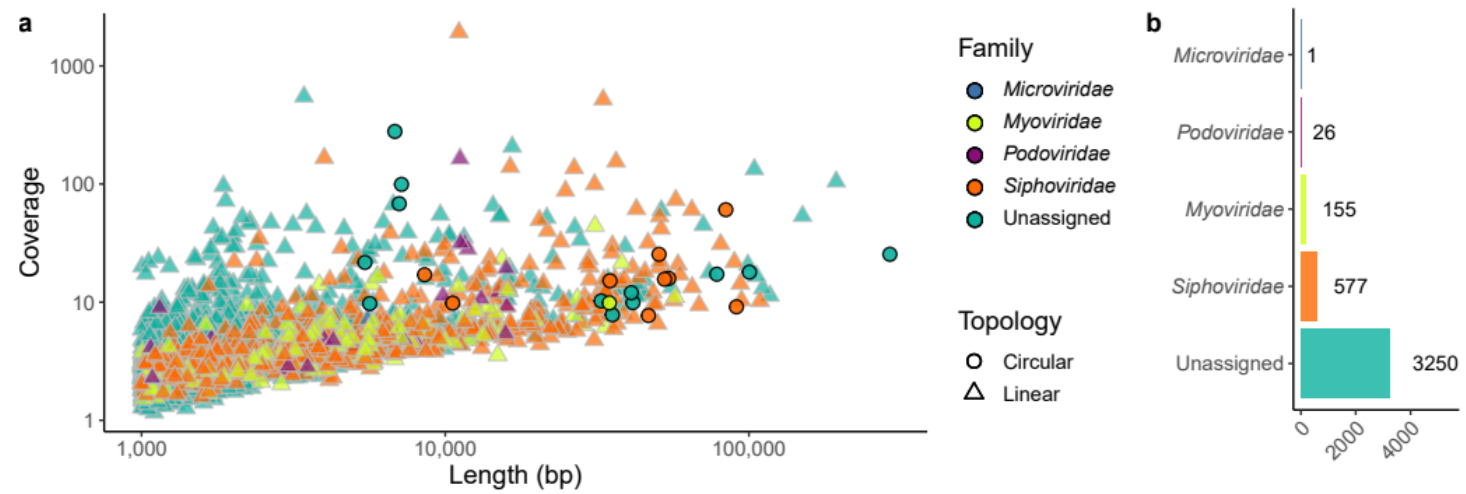

c

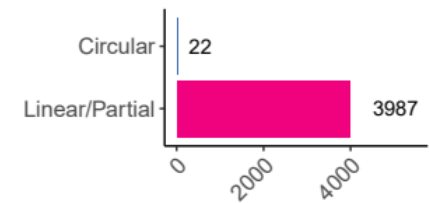

d

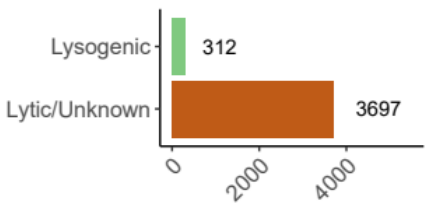

e

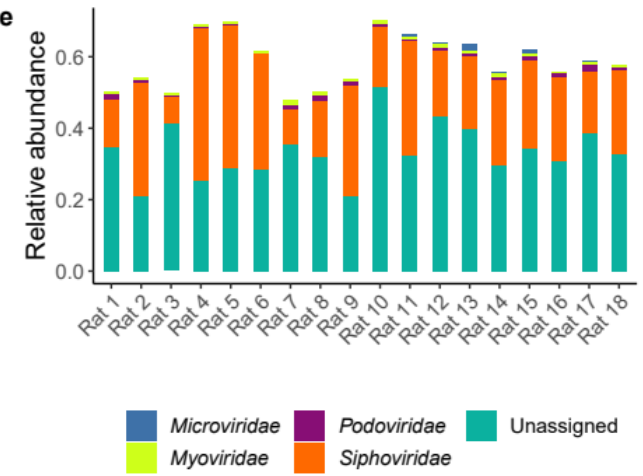

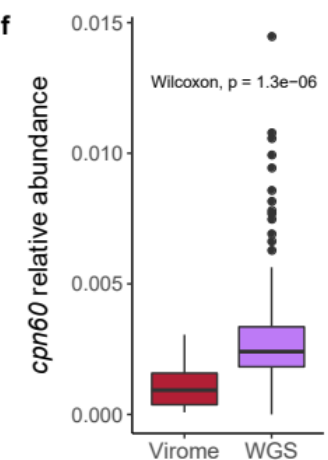

\section{Figure 1.}


bioRxiv preprint doi: https://doi.org/10.1101/2021.03.29.437468; this version posted March 29, 2021. The copyright holder for this preprint (which was not certified by peer review) is the author/funder, who has granted bioRxiv a license to display the preprint in perpetuity. It is made available under aCC-BY-NC-ND 4.0 International license.

a Virome

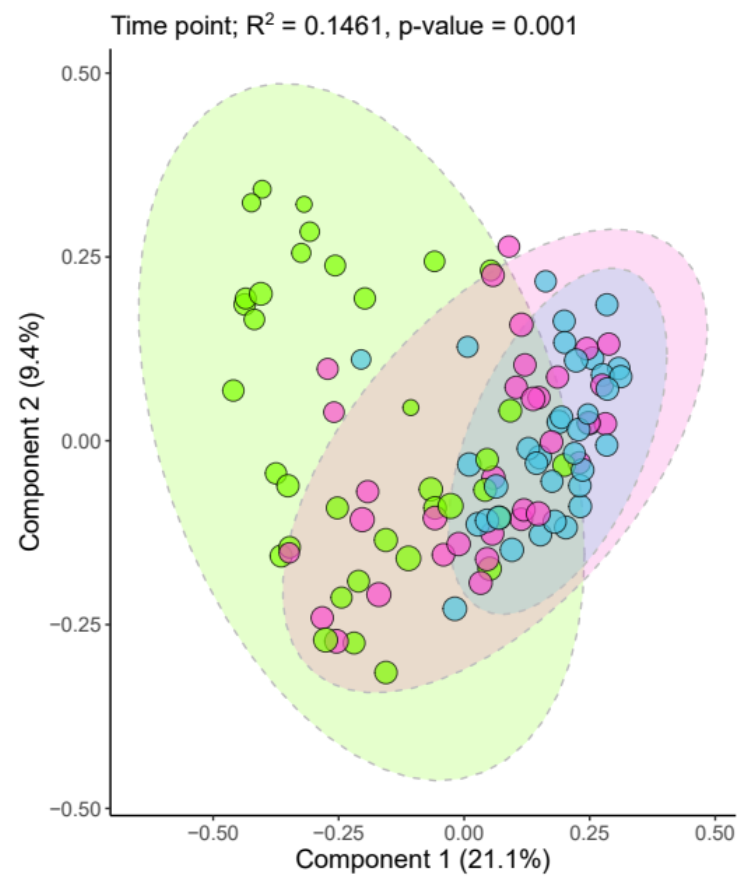

b Microbiome

Time point; $\mathrm{R}^{2}=0.1328, \mathrm{p}$-value $=0.001$

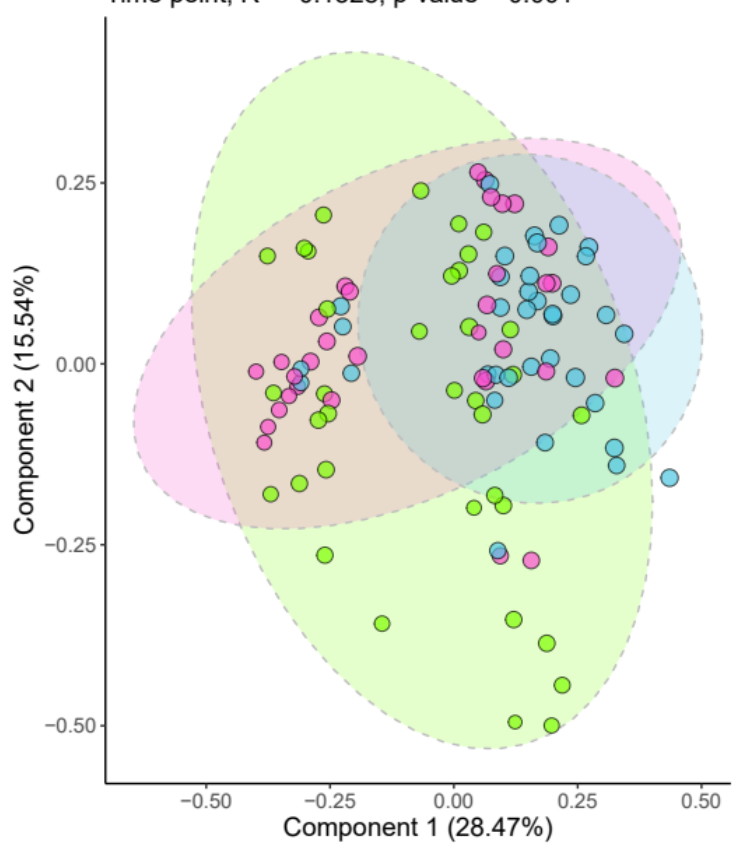

Shannon index $\bigcirc 1 \bigcirc 2 \bigcirc 3 \bigcirc 4 \bigcirc 5$

Timepoint $\bigcirc$ Base $\bigcirc$ T1 $\bigcirc$ T5

\section{Figure 2.}


A Sham

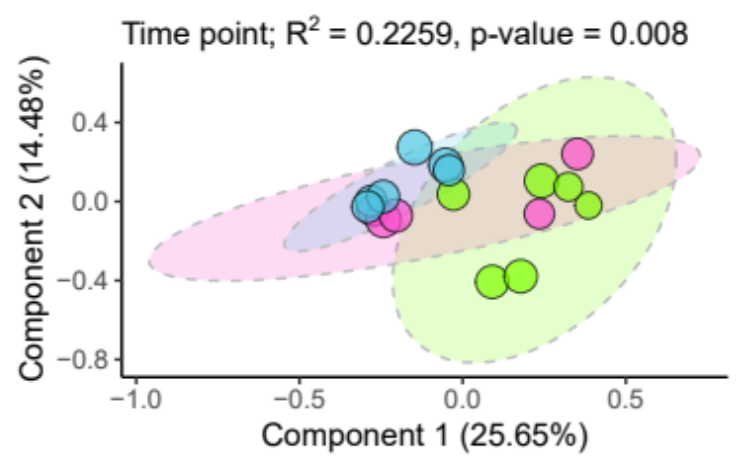

C Monomer

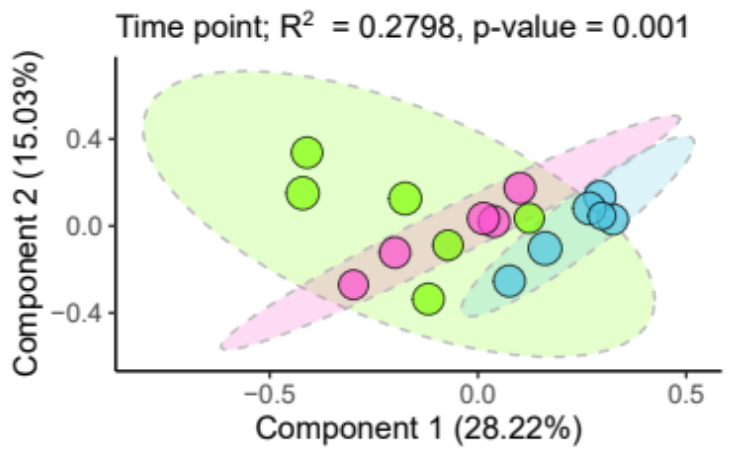

E PFF

Time point; $R^{2}=0.2392, \mathrm{p}$-value $=0.005$

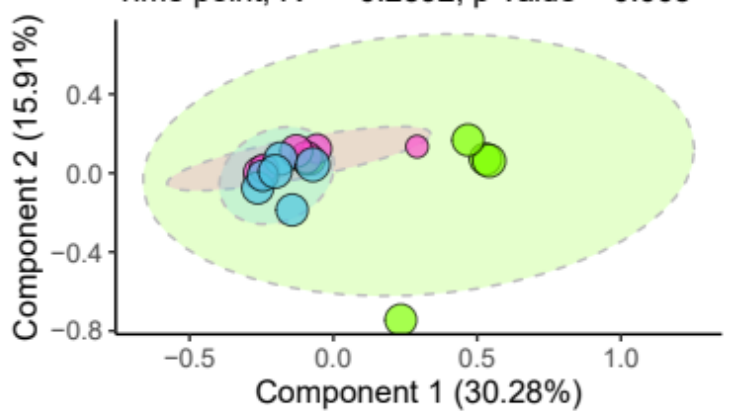

B LPS

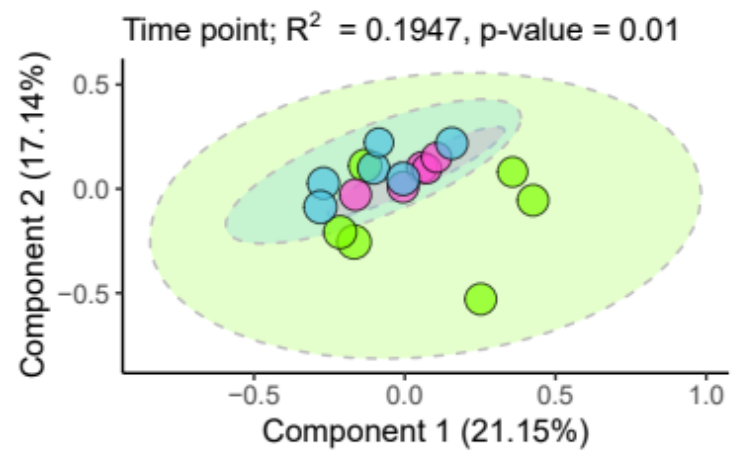

D Monomer + LPS

Time point; $R^{2}=0.2755$, $p$-value $=0.001$

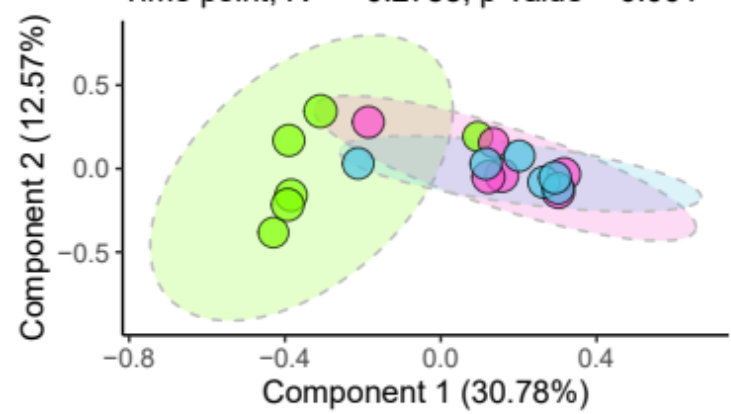

F $\quad$ PFF + LPS
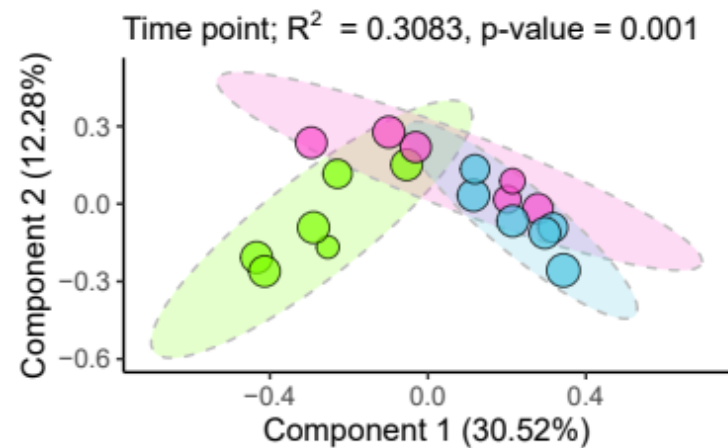

Shannon index $\bigcirc 1 \bigcirc 2 \bigcirc 3 \bigcirc 4 \bigcirc 5$

Timepoint $\bigcirc$ Base $\bigcirc$ T1 $\bigcirc$ T5

\section{Figure 3.}


a

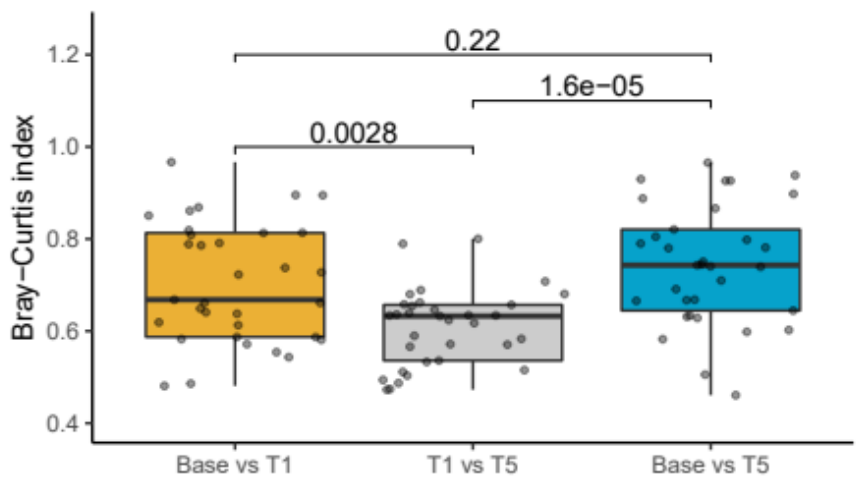

b

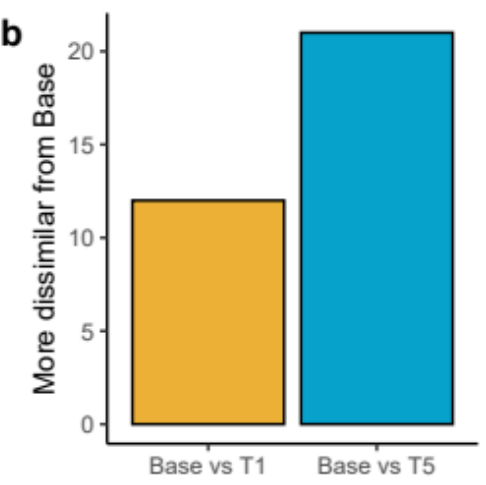

c

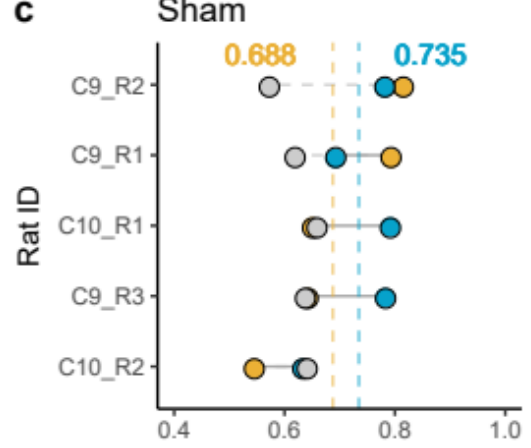

e

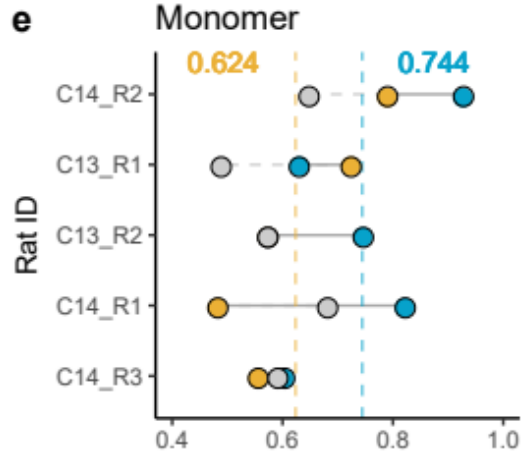

g

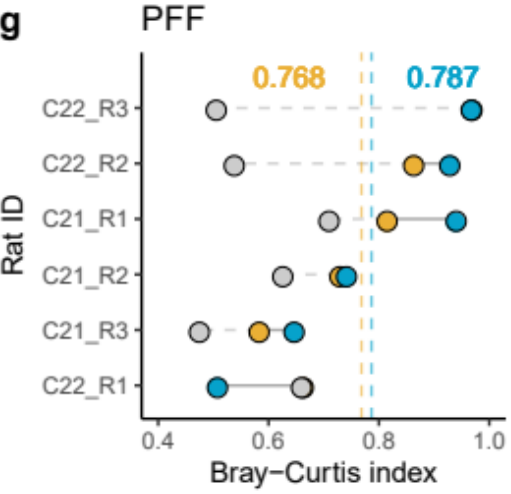

$\bigcirc$ Base vs T1

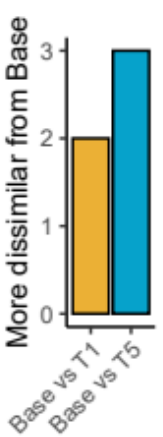

d
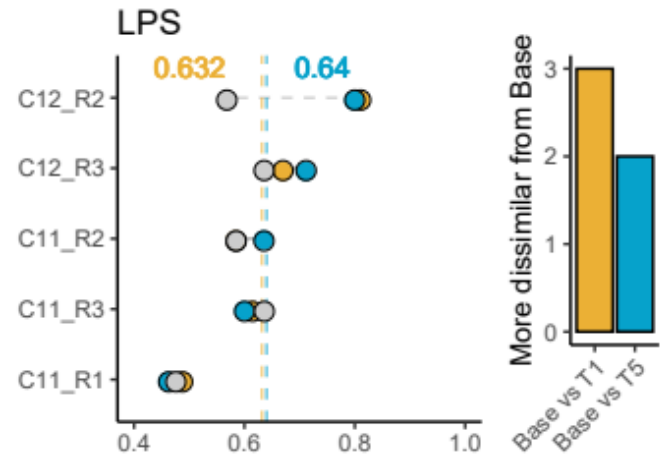

f

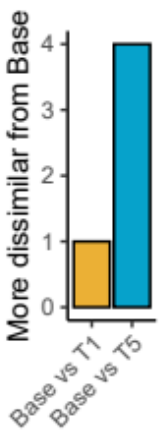

Monomer + LPS
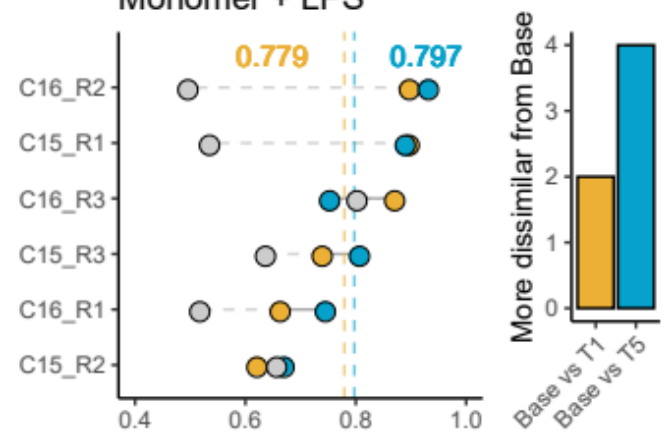

h
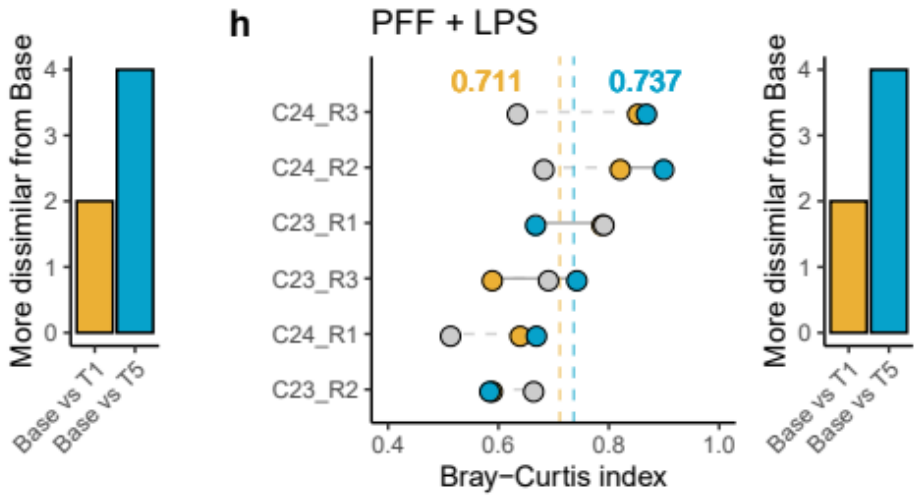

\section{Figure 4.}


a Sham

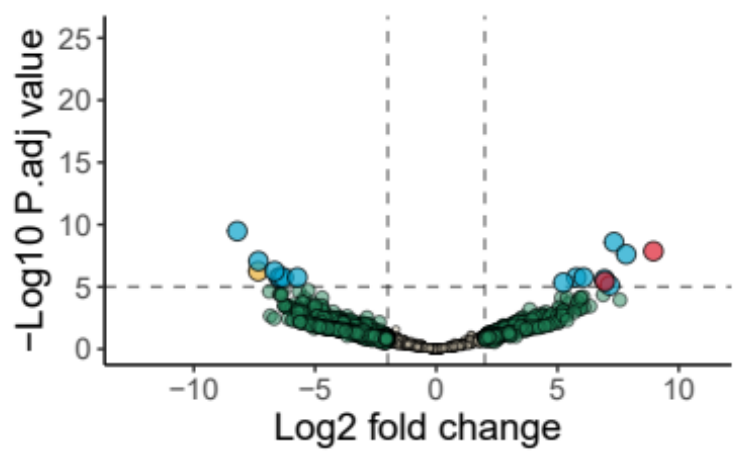

c Monomer
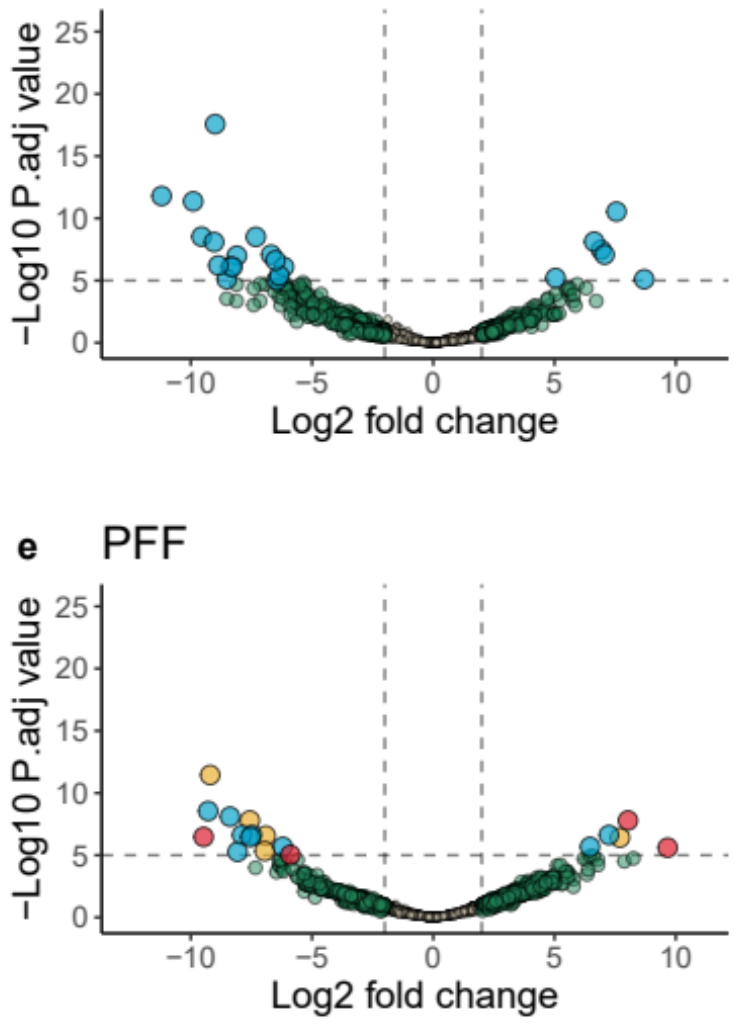

\section{b LPS}

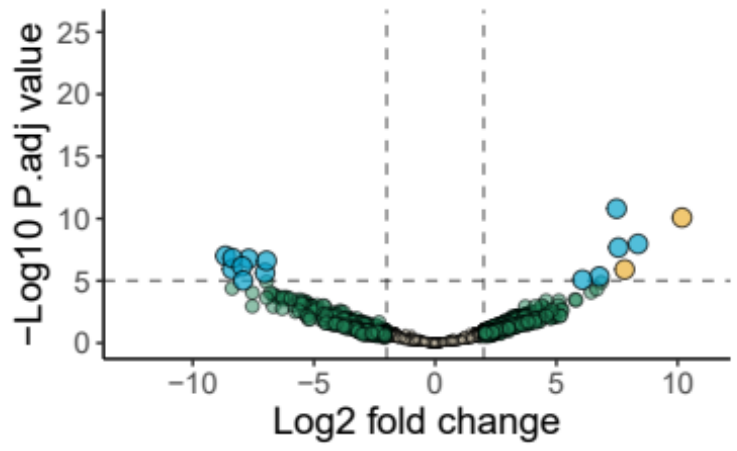

d Monomer + LPS

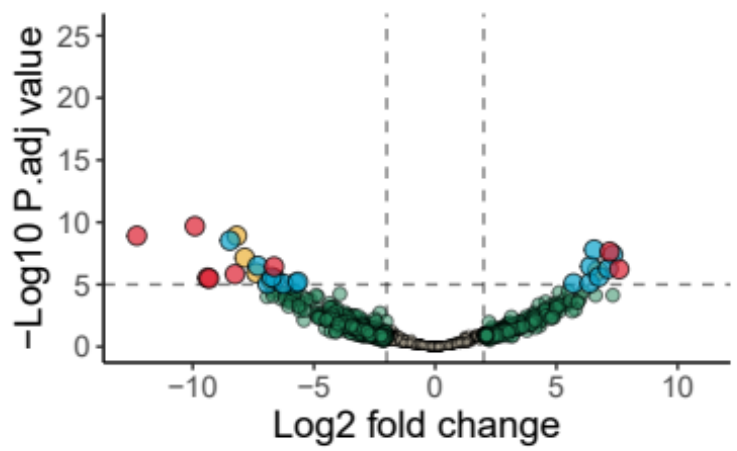

f $\quad$ PFF + LPS

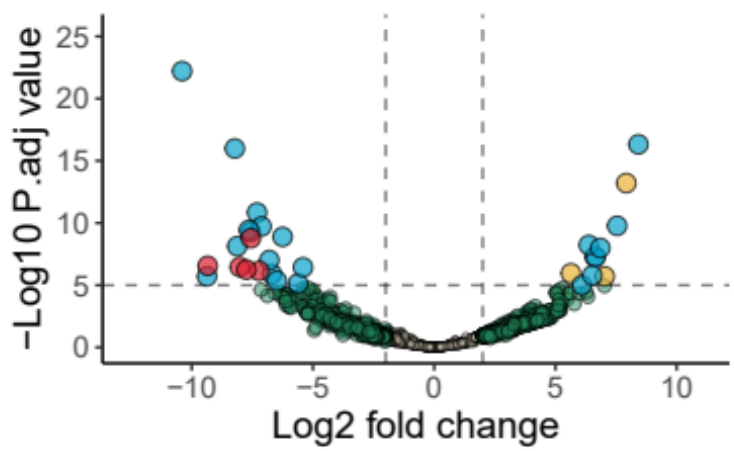

Significant in T1 and T5

Significant in T1

Significant in T5

Altered, but not significant $\bigcirc$ Not altered

696 Figure 5. 
bioRxiv preprint doi: https://doi.org/10.1101/2021.03.29.437468; this version posted March 29, 2021. The copyright holder for this preprint (which was not certified by peer review) is the author/funder, who has granted bioRxiv a license to display the preprint in perpetuity. It is made available under aCC-BY-NC-ND 4.0 International license.

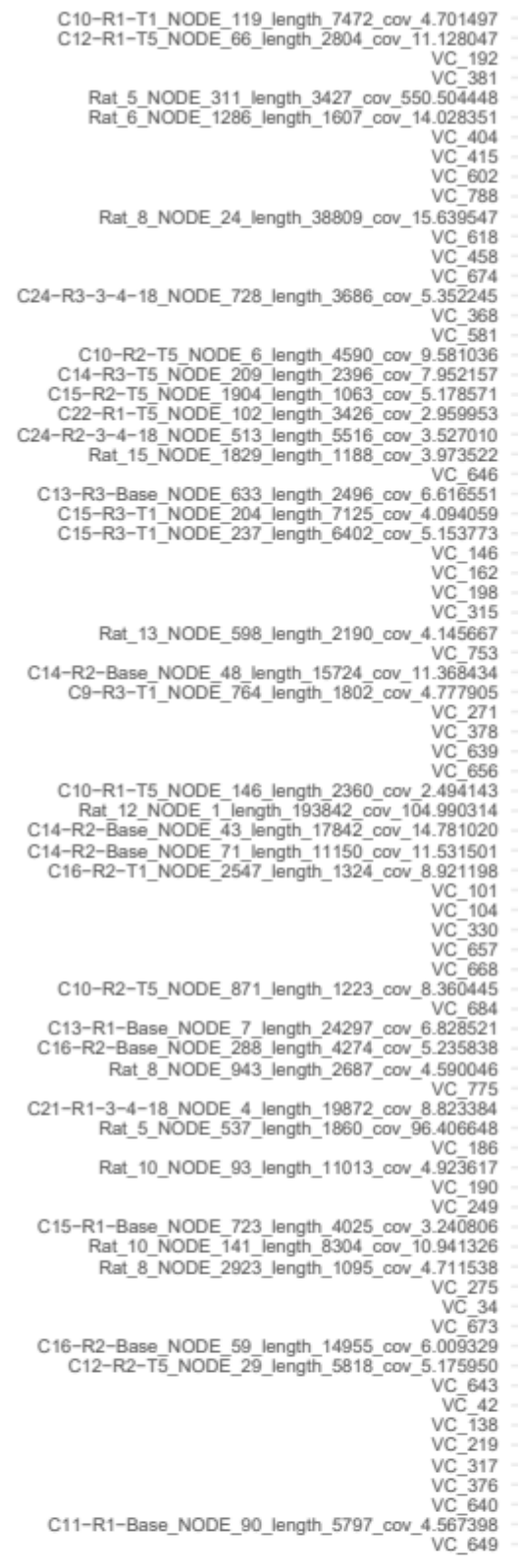

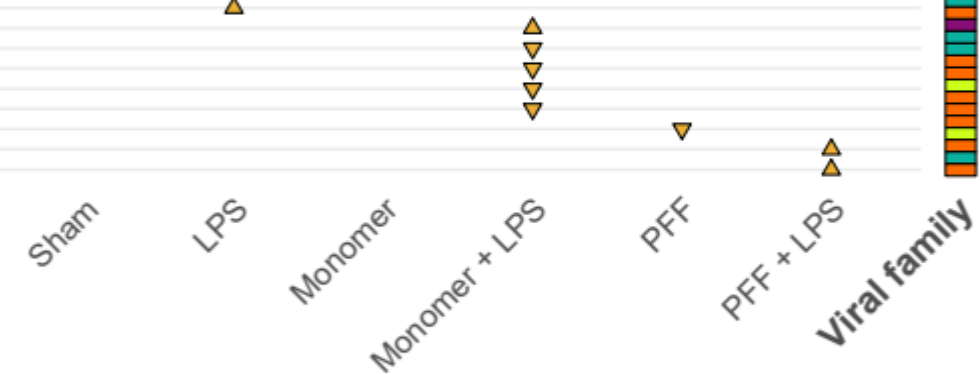

$\Delta$
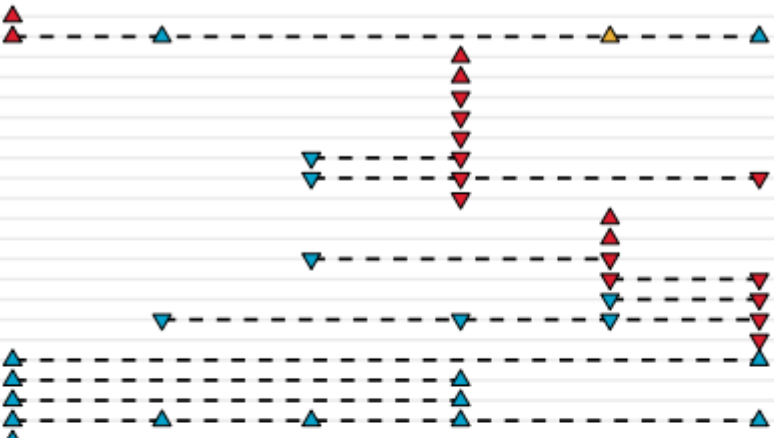

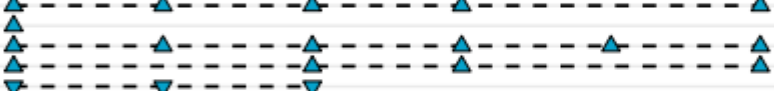

$\vec{\nabla}$

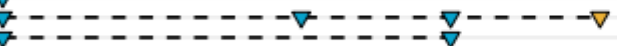

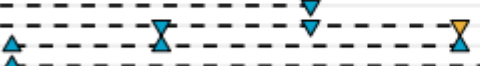

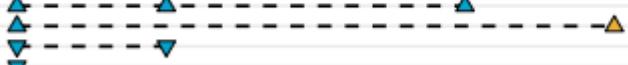

$\nabla$<smiles>[Te][Te]</smiles>

\section{$\Delta$}

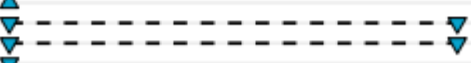

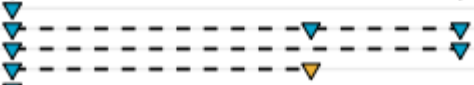

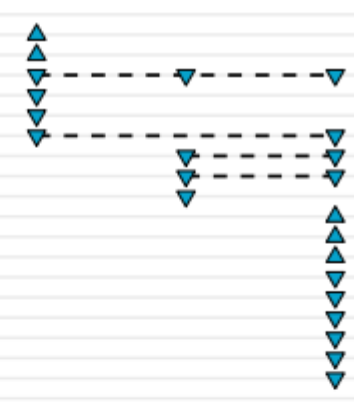

$\nabla$

$\Delta$

$\nabla$

$\triangle$ Increased $\nabla$ Decreased

Significant in $\mathrm{T} 1$ and $\mathrm{T} 5$

Significant in $\mathrm{T} 1$

Significant in T5

\section{Figure 6.}




\section{Supplementary figure legends}

699 Supplementary figure 1. Relative abundance of predicted viral taxa in WGS data.

700 Aggregation of sequencing data for each rat faecal sample investigated by Demovir predicted

701 viral taxonomic assignment.

703 Supplementary table 1. Alpha-diversity analysis of rat faecal viromes. Wilcoxon-paired

704 statistical comparisons of rat faecal virome alpha-diversities, with Bonferroni correction, 705 using both viral and WGS sequencing data.

707 Supplementary figure 2. Longitudinal changes in the relative abundance of rat faecal

708 lysogenic phages by treatment. P-values for specific group comparisons were performed 709 using Wilcoxon-paired tests, while the Kruskal-Wallis test was performed across all groups.

711 Supplementary figure 3. Overlapping rat faecal viruses differentially altered by alpha712 synuclein treatment. 
bioRxiv preprint doi: https://doi.org/10.1101/2021.03.29.437468; this version posted March 29, 2021. The copyright holder for this preprint (which was not certified by peer review) is the author/funder, who has granted bioRxiv a license to display the preprint in perpetuity. It is made available under aCC-BY-NC-ND 4.0 International license.

\section{Supplementary figures and tables:}

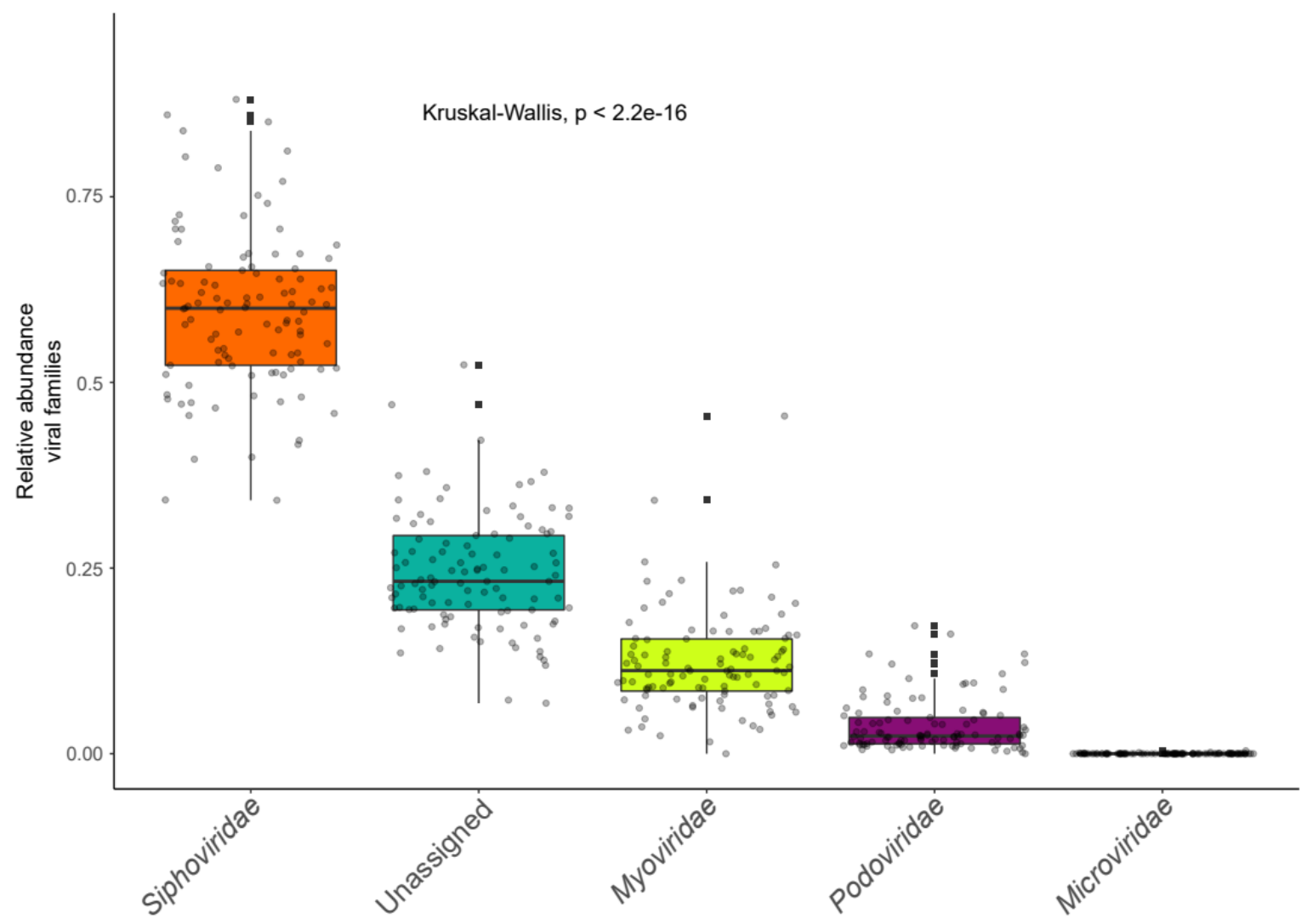

\section{Supplementary figure 1.}


bioRxiv preprint doi: https://doi.org/10.1101/2021.03.29.437468; this version posted March 29, 2021. The copyright holder for this preprint (which was not certified by peer review) is the author/funder, who has granted bioRxiv a license to display the preprint in perpetuity. It is made available under aCC-BY-NC-ND 4.0 International license.

\section{Supplementary table 1.}

716

\begin{tabular}{|c|c|c|c|c|c|c|}
\hline & Data & Group 1 & Group 2 & P-value & $\begin{array}{l}\text { Bonferroni } \\
\text { P-value }\end{array}$ & Significant \\
\hline 1 & Virome & Sham & LPS & 0.394 & 1.000 & ns \\
\hline 2 & WGS & Sham & LPS & 0.0177 & 0.270 & * \\
\hline 3 & Virome & Sham & Monomer & 0.122 & 1.000 & ns \\
\hline 4 & WGS & Sham & Monomer & 0.4745 & 1.000 & ns \\
\hline 5 & Virome & Sham & Monomer + LPS & 0.083 & 1.000 & ns \\
\hline 6 & WGS & Sham & Monomer + LPS & 0.2447 & 1.000 & ns \\
\hline 7 & Virome & Sham & PFF & 0.062 & 0.920 & ns \\
\hline 8 & WGS & Sham & PFF & 0.0380 & 0.570 & * \\
\hline 9 & Virome & Sham & PFF + LPS & 0.525 & 1.000 & ns \\
\hline 10 & WGS & Sham & PFF + LPS & 0.1837 & 1.000 & ns \\
\hline 11 & Virome & LPS & Monomer & 0.357 & 1.000 & ns \\
\hline 12 & WGS & LPS & Monomer & 0.0145 & 0.220 & * \\
\hline 13 & Virome & LPS & Monomer + LPS & 0.083 & 1.000 & ns \\
\hline 14 & WGS & LPS & Monomer + LPS & 0.3687 & 1.000 & ns \\
\hline 15 & Virome & LPS & PFF & 0.219 & 1.000 & ns \\
\hline 16 & WGS & LPS & PFF & 0.6598 & 1.000 & ns \\
\hline 17 & Virome & LPS & $P F F+L P S$ & 0.782 & 1.000 & ns \\
\hline 18 & WGS & LPS & PFF + LPS & 0.3514 & 1.000 & ns \\
\hline 19 & Virome & Monomer & Monomer + LPS & 0.483 & 1.000 & ns \\
\hline 20 & WGS & Monomer & Monomer + LPS & 0.0773 & 1.000 & ns \\
\hline 21 & Virome & Monomer & PFF & 0.636 & 1.000 & ns \\
\hline 22 & WGS & Monomer & PFF & 0.0054 & 0.081 & $\star *$ \\
\hline 23 & Virome & Monomer & PFF + LPS & 0.386 & 1.000 & ns \\
\hline 24 & WGS & Monomer & PFF + LPS & 0.1434 & 1.000 & ns \\
\hline 25 & Virome & Monomer + LPS & PFF & 0.791 & 1.000 & ns \\
\hline 26 & WGS & Monomer + LPS & PFF & 0.1038 & 1.000 & ns \\
\hline 27 & Virome & Monomer + LPS & PFF + LPS & 0.097 & 1.000 & ns \\
\hline 28 & WGS & Monomer + LPS & PFF + LPS & 0.8391 & 1.000 & ns \\
\hline 29 & Virome & PFF & PFF + LPS & 0.192 & 1.000 & ns \\
\hline 30 & WGS & PFF & $\mathrm{PFF}+\mathrm{LPS}$ & 0.1427 & 1.000 & ns \\
\hline
\end{tabular}


bioRxiv preprint doi: https://doi.org/10.1101/2021.03.29.437468; this version posted March 29, 2021. The copyright holder for this preprint (which was not certified by peer review) is the author/funder, who has granted bioRxiv a license to display the preprint in perpetuity. It is made available under aCC-BY-NC-ND 4.0 International license.

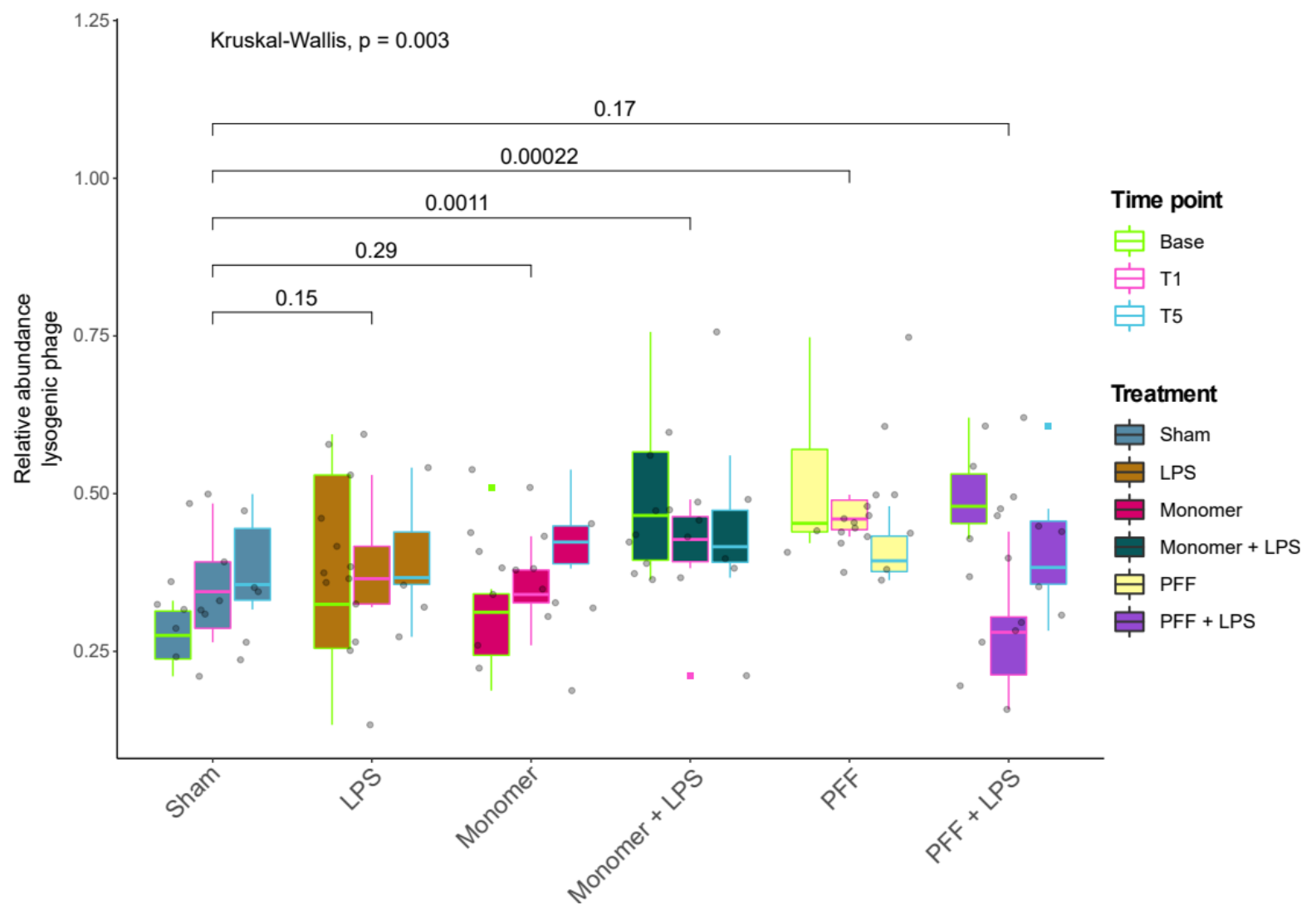

717 Supplementary figure 2. 
bioRxiv preprint doi: https://doi.org/10.1101/2021.03.29.437468; this version posted March 29, 2021. The copyright holder for this preprint (which was not certified by peer review) is the author/funder, who has granted bioRxiv a license to display the preprint in perpetuity. It is made available under aCC-BY-NC-ND 4.0 International license.

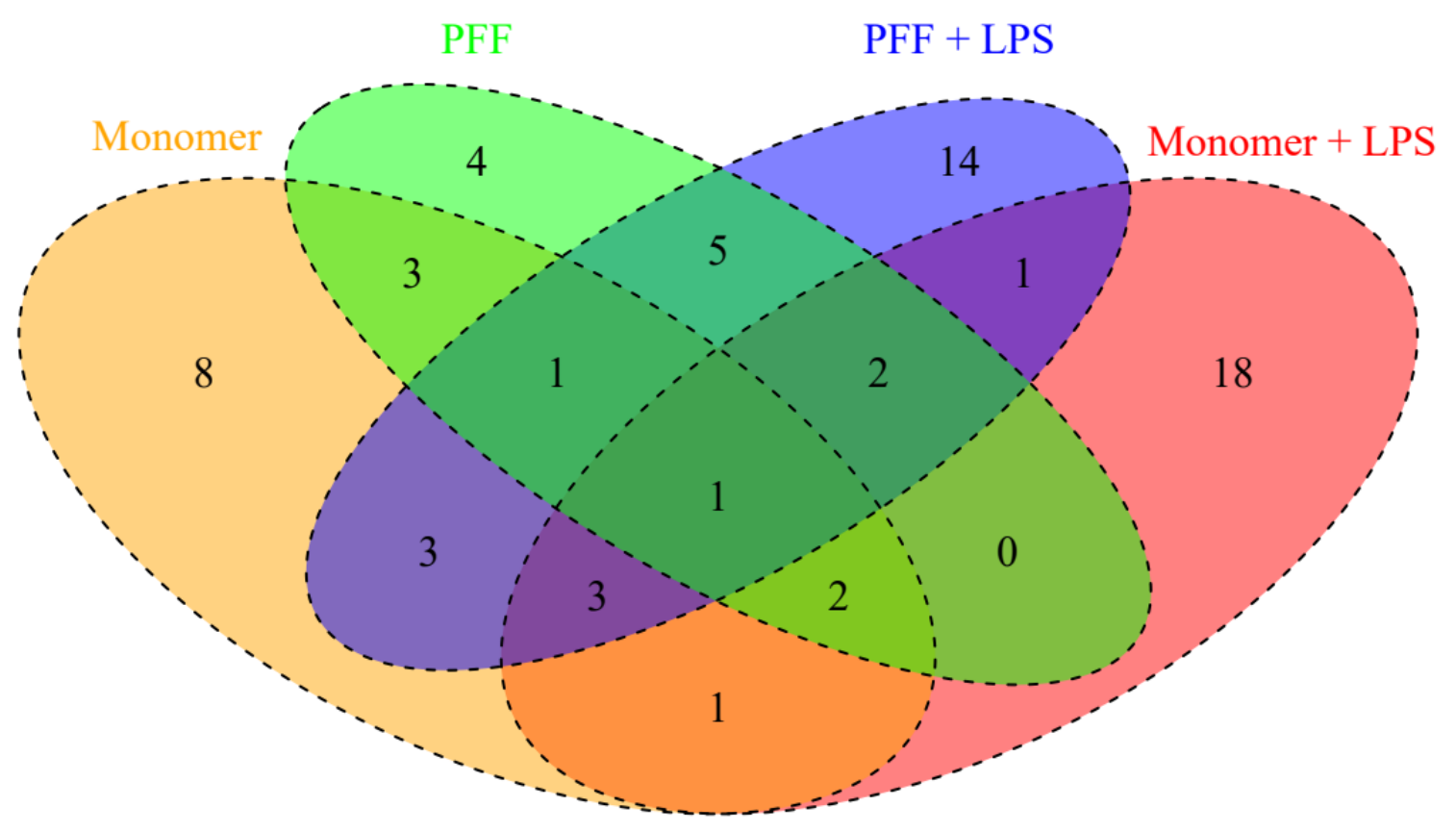

718 Supplementary figure 3. 